\title{
COMERCIO MEDITERRÁNEO EN EL CASTRO DE MONTEALEGRE (PONTEVEDRA, GALICIA). SIGLO II A. C. - INICIOS DEL SIGLO I D. C.
}

\author{
ALFREDO GONZÁLEZ-RUIBAL*, RAFAEL RODRÍGUEZ MARTÍNEZ ${ }^{* *}$, ROBERTO ABOAL FERNÁNDEZ *** y \\ VIRGINIA CASTRO HIERRO ****
}

\section{RESUMEN}

El castro de Montealegre, en la costa de Galicia, ha proporcionado en recientes excavaciones un interesante conjunto de importaciones mediterráneas, de mediados del siglo II a.C. a inicios del siglo I d.C. principalmente. El comercio tardopúnico y romano preaugusteo en el noroeste ibérico era hasta hace poco escasamente conocido, frente a las relaciones comerciales del período julio-claudio. Los objetos que llegaron a este finis terrae incluyen ánforas tardopúnicas (Mañá C2b), ibéricas (Pellicer D) e itálicas (Dressel 1), kalathoi de Cataluña y cerámica común, entre otras cosas. El período julio-claudio está asimismo bien representado por numerosas ánforas, fundamentalmente de la Bética (Dressel 2/4, Haltern 70, Dressel 7/11). La variedad y cantidad de importaciones desde mediados del siglo II a.C. en adelante demuestra la gran integración de la costa galaica en las redes mediterráneas desde antes de la conquista romana.

\section{ABSTRACT}

The Iron Age hillfort of Montealegre, in the Atlantic coast of Galicia (NW Spain), has yielded an interesting array of Mediterranean imports during the last excavations (2003-2004). These imports span mainly from the mid- $2^{\text {nd }} \mathrm{c}$. BC to the early $1^{\text {st }} \mathrm{c}$. AD. The late Punic and early Roman trade in the northwest of Iberia was until now scarcely known, unlike the JulioClaudian commercial relations. The artefacts that made their way to this end of the world include late Punic (Mañá C2b), Iberian (Pellicer D) and Italic (Dressel 1) amphorae, kalathoi from Catalonia, and common ware, among other things. The Julio-Claudian period is also well represented, especially by numerous amphorae (Dressel 2/4, Haltern 70, Dressel 7/11). The variety and quantity of imports from the mid- $2^{\text {nd }} \mathrm{c}$. BC onwards proves the strong integration of the Galician coast in the Mediterranean network before the Roman conquest of the area.

PALABRAS CLAVE: Gallaecia, Segunda Edad del Hierro, castros costeros, comercio tardopúnico, comercio romano, ánforas.

KEY WORDS: Gallaecia (NW Iberia), Late Iron Age, coastal hillforts, late Punic trade, Roman trade, amphorae.

\section{INTRODUCCIÓN}

Los castros del noroeste peninsular han proporcionado un elevado número de importaciones mediterráneas de época augustea y julio-claudia. La intensidad de las relaciones comerciales con el imperio romano tras la ocupación efectiva de Gallaecia (ca. 29-19 a.C.) es bien conocida al menos desde el comienzo de la arqueología "científica" en la zona: Las excavaciones en grandes castros tardíos como Santa Trega (Pontevedra) en Galicia (Calvo 2001) y Briteiros (Braga) en el noroeste de Portugal (Cardozo 1976), durante la primera mitad del siglo XX contribuyeron especialmente a poner de manifiesto la importancia de estas relaciones, dada la gran cantidad de cerámica romana recuperada en las intervenciones, especialmente ánforas altoimperiales y terra sigillata. Por otro lado, durante los años 80 comenzó a quedar clara la relevancia del comercio púnico con la denominada Cultura Castreña, especialmente en el noroeste de Portugal y las Rías Bajas, a partir del siglo V a.C. Castros como Romariz (Silva 1986, 40-41) o A Lanzada (Suárez Otero y Fariña 1990)—por desgracia nunca publicados de forma monográfica-suministraron importantes lotes de importaciones prerromanas.

Así pues se podrían distinguir con claridad tres grandes episodios de relaciones mediterráneas en la zona galaica durante el primer milenio: 1) comercio con fenicios y, sobre todo, tartésicos (s. IX-VI a.C.) (Torres 2005); 2) comercio púnico (s. V-II a.C.); 3) comercio romano (s. I a.C. - I d.C.). Sin embargo, este esquema simplifica una realidad más compleja, especialmente por lo que se refiere al paso del comercio púnico al propiamente romano. Sabemos por las fuentes antiguas que la ruta del Noroeste siguió en manos gadiritas durante todo el siglo II a.C. En el año 96 a.C. se produce la primera expedición romana hacia las Cassitérides de que tengamos documentación, la de Publio Craso. Según Estrabón (Str. 3, 5, 11), Craso divulgó las rutas hacia las

\footnotetext{
* Departamento de Prehistoria, Facultad de Geografía e Historia. Universidad Complutense de Madrid. 28040. Madrid. aruibal@ghis.ucm.es

** Arqueólogo. Deputación Provincial de Pontevedra. Avda. Montero Ríos, s/n. 36071 Pontevedra. rafarodriguez76@mixmail.com

**** Instituto de Estudos Galegos Padre Sarmiento. Rúa San Roque 2. Santiago de Compostela. 15704. A Coruña. phraf@usc.es / phvirch@usc.es.
} 


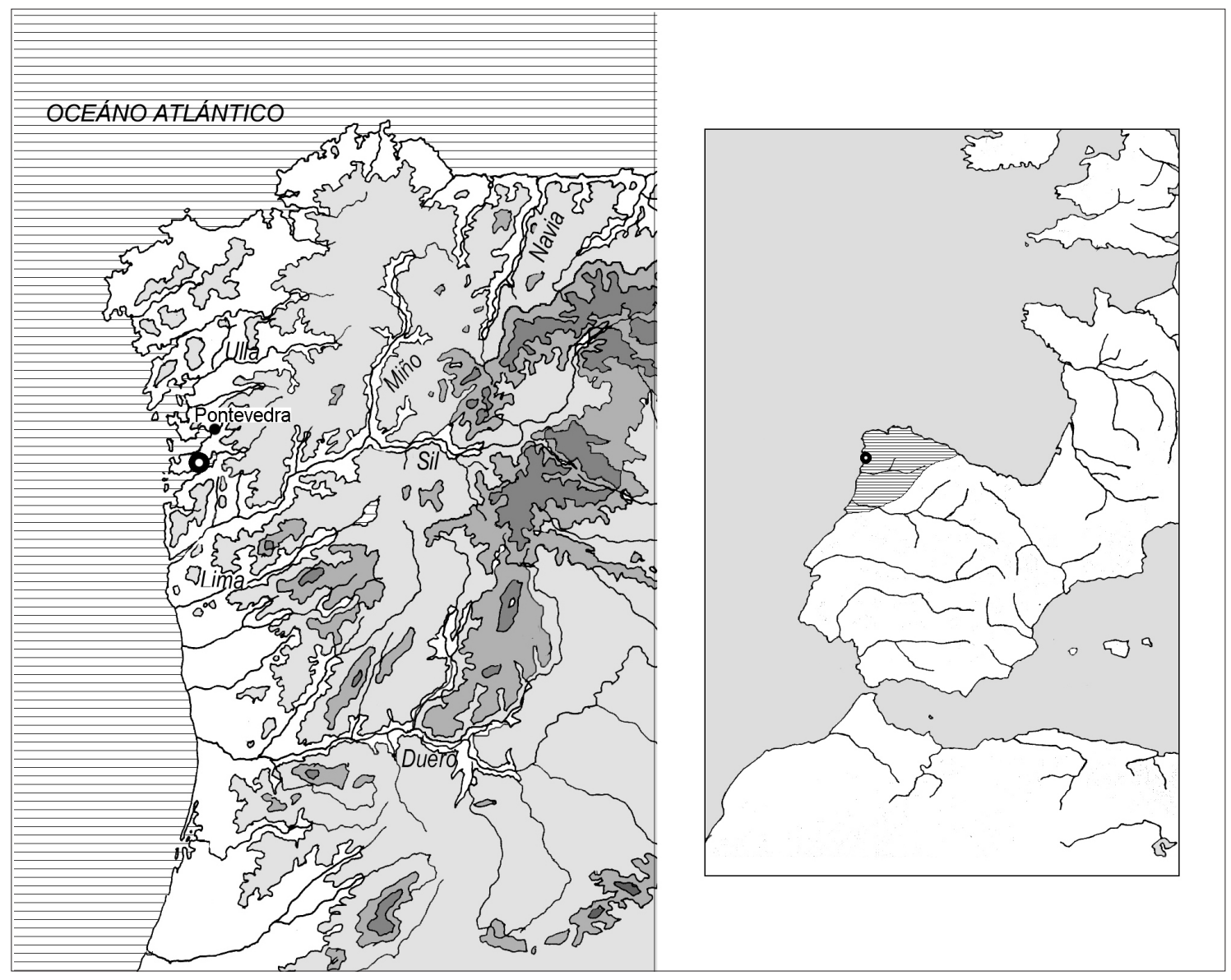

Figura 1. Localización de Montealegre en el Noroeste y en la fachada atlántica (en trama: área de extensión de la Cultura Castreña del Noroeste).

tierras del estaño a quienes deseaban conocerlas-es decir, navegantes romanos que no estaban vinculados a las antiguas ciudades púnicas del Estrecho. Más tarde, en 61 a.C., Julio César llegó al puerto de los ártabros, Brigantium, en el norte de Galicia (Dión Casio 37, 5253) y se encontró a una población pacífica y bien dispuesta para el comercio. Al fin y al cabo, llevaban manteniendo relaciones con los navegantes púnicos desde al menos tres siglos antes, según demuestran los hallazgos subacuáticos del puerto de A Coruña (Naveiro 1982). Estrabón $(3,3,5)$ nos informa de los repetidos intentos romanos de apoderarse de las lucrativas rutas del estaño:

"Antes únicamente los fenicios realizaban este comercio desde Gades, ocultando a todos la ruta marítima, y cuando los romanos persiguieron a cierto navegante para conocer aquellos emporios, éste voluntariamente encalló su barco en unos bajos y arrastró a la misma desgracia a los que le seguían, mientras él se salvaba del naufragio y recibía de su gobierno el precio de la carga perdida. Pero los romanos, intentándolo muchas veces, llegaron a conocer la ruta".

(Traducción y edición. - Estrabón, geografía. Libros III-IV. Traducciones, introducciones y notas de M. ${ }^{\mathrm{a}}$ José Meana y Félix Piñero. Madrid, Gredos, 1992).

Es de suponer que las expediciones de Craso y César se incluyen en estos intentos de acceder a las fuentes metalíferas de Gallaecia.

El período comprendido entre el período posterior a la Segunda Guerra Púnica y la conquista augustea era escasamente conocido en el Noroeste ibérico hasta hace poco en lo referente a las relaciones con el Mediterráneo. Su identidad quedaba disuelta entre lo propiamente romano y lo púnico. De este modo, las ánforas Dressel 1 y la cerámica campaniense se han publicado con frecuencia junto a producciones altoimperiales y se han venido considerando materiales residuales. En parte, esto se debe a que dichos materiales aparecían en estratos revueltos o de relleno, debajo de los niveles julio- 


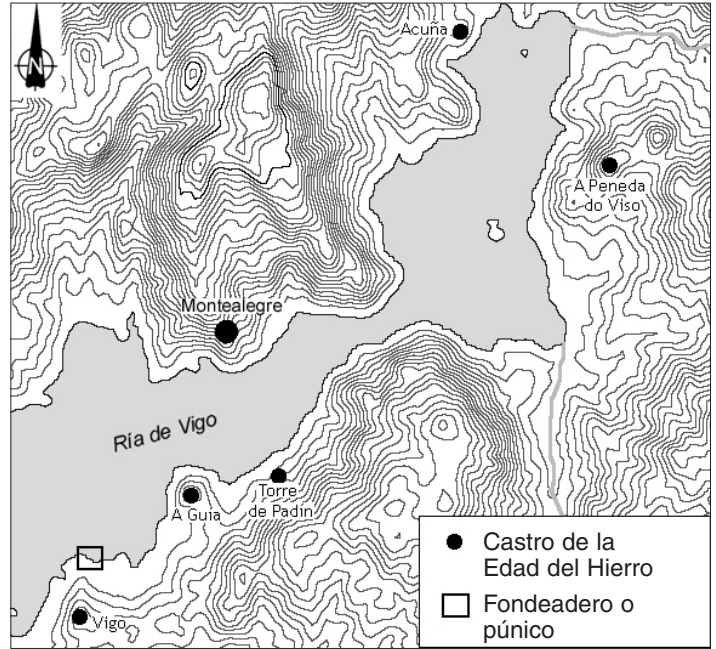

Figura 2. Localización de Montealegre dentro de la Ría de Vigo.

claudios que en muchos de los grandes oppida galaicos constituyen el episodio mejor documentado. En otras ocasiones, la cerámica tardorrepublicana aparece en cantidades ínfimas, lo que no permite definir propiamente una fase preaugustea de comercio mediterráneo. Por otro lado, las ánforas tardopúnicas y los kalathoi ibéricos se han identificado mal en ciertos casos (p.ej. Hidalgo 1985); se han incluido dentro de trabajos generales sobre comercio romano, pese a haber sido correctamente identificadas (Naveiro 1982), o simplemente no se han publicado. La misma suerte ha corrido la cerámica común tardorrepublicana. En algunas ocasiones se ha considerado como un único lote con la altoimperial, en otras-en el caso de las que aparecen en niveles más antiguos-se ha asociado a la púnica más reciente. Algunas ánforas tampoco se han reconocido adecuadamente: tradicionalmente se ha confundido la Haltern 70 con la Dressel 7/11 (p.ej. Hidalgo 1985, 26, véase crítica en Naveiro 1991, 180), mientras que la LC 67 ha sido etiquetada de diferentes maneras y datada en época julio-claudia (p.ej. Peña 1986). En este caso, no obstante, el error es excusable, dado que la definición del tipo (Fabião 1989) es posterior a buena parte de las excavaciones en castros galaicos tardíos.

El castro de Montealegre (Aboal y Hierro 2006) que ahora presentamos es excepcional precisamente porque el período comprendido entre inicios del siglo II a.C. y fines del siglo I a.C. está especialmente bien documentado. Al igual que en muchos otros castros, también aquí existe un importante nivel julio-claudio-que será objeto de estudio en este artículo igualmente-pero por fortuna dicho nivel no supuso el arrasamiento del período previo. Al contrario, el nivel altoimperial, al menos en el sector de habitación, se encontró considerablemente alterado. Los materiales recuperados en este yacimiento permiten calibrar mejor la importancia del comercio preaugusteo en el Noroeste y describir, con más detalle, su evolución, desde inicios del siglo II a.C. hasta mediados del siglo I d.C.

\section{EL CASTRO DE MONTEALEGRE}

El castro de Montealegre (Moaña, Pontevedra) se enclava en la costa meridional de la Península do Morrazo, en la Ría de Vigo, a escasa distancia del puente de Rande, por donde pasa actualmente la autopista AP-9 que une Portugal y A Coruña (figs. 1 y 2). Este hecho no carece de interés. El puente se erigió en la zona más estrecha de la Ría de Vigo, en un punto donde ésta se estrangula y en cuyos alrededores se construyó el castillo de Ubeiras (San Adrián de Cobres) durante el siglo XVII. La importancia del castro y la presencia de importaciones pueden hallarse en relación con su notable posición estratégica respecto a este accidente geográfico. El poblado, pese a no hallarse directamente bañado por el mar como sucede con otros poblados costeros emplazados en un cabo-p.ej. Baroña (Calo y Soeiro 1986), Neixón (Ayán 2005)—dispone de un acceso fácil a la ría y en concreto a zonas de playa y ensenada. Así lo demuestra, entre otras cosas, la enorme potencia de sus vertederos de conchas (concheiros) - los cuales fueron inicialmente estudiados por Vázquez Varela (1977).

El castro se sitúa en un emplazamiento característico de la Primera Edad del Hierro: ocupa un espolón elevado con una amplia visibilidad sobre los valles circundantes y la ría. El yacimiento fue objeto de intervención arqueológica por primera vez en los años 20 del siglo pasado. Losada Diéguez (1927) descubrió entonces varias estructuras de piedra de planta circular, un vertedero de conchas, restos faunísticos, entre los que se encontraban cornamentas de ciervo, y numerosos materiales cerámicos, la mayor parte de ellos de la Segunda Edad del Hierro y alguna cerámica a torno pintada de procedencia mediterránea. En éstas y posteriores intervenciones se descubrieron también hachas de bronce de talón y dos anillas.

Tras la exploración de Losada, en el yacimiento no se practicó ninguna intervención sistemática hasta el año 2003. La construcción del Corredor do Morrazo obligó entonces a realizar excavaciones en dos sectores del poblado que se verían afectados por la construcción de sendas bocas de túnel. Tales excavaciones, que fueron llevadas a cabo por el Laboratorio de Patrimonio, Paleoambiente e Paisaxe (Instituto de Investigaciones Tecnológicas de la Universidad de Santiago de Compostela ${ }^{1}$ ), bajo la dirección de uno de nosotros (Roberto

\footnotetext{
1 Unidad Asociada al CSIC a través del Instituto de Estudos Galegos Padre Sarmiento.
} 


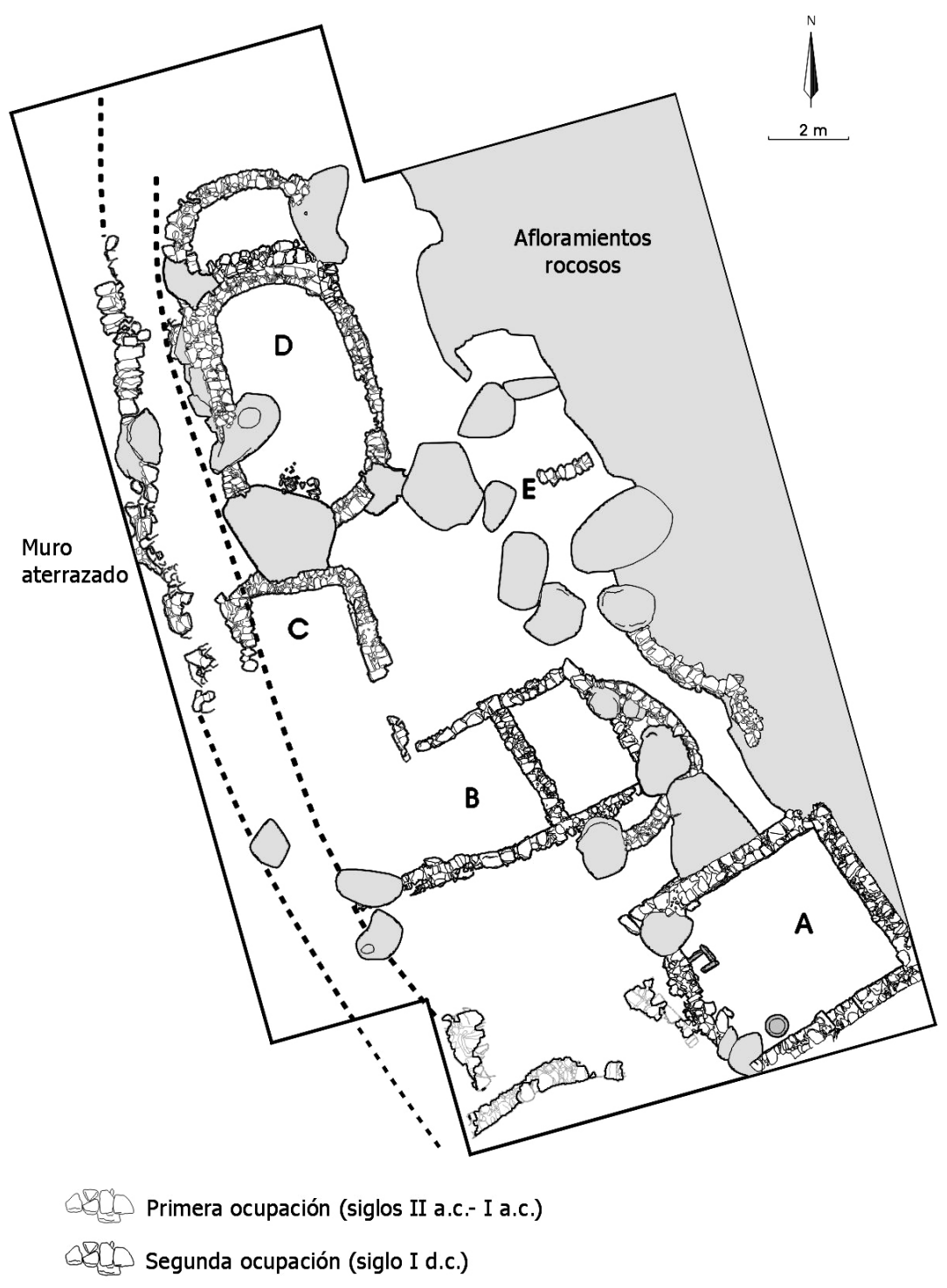

Figura 3. Planimetría del sector residencial: ladera oeste.

Aboal Fernández), pusieron al descubierto un sector residencial en la ladera oeste del castro y un gran vertedero de conchas (concheiro) en la ladera este.

Las características de las obras del túnel del citado corredor obligaron a plantear los trabajos en las dos laderas como dos excavaciones independientes aunque ejecutadas de manera simultánea. Los resultados obtenidos en la excavación muestran dos zonas del castro con funcionalidades totalmente dispares. Mientras que en la ladera W se identificó un espacio de habitación claramente arquitecturizado, que fue ocupado durante un período cronológico amplio, en la ladera E se documentó un área "marginal" relacionada con actividades de la vida en el castro, pero no de índole habitacional (cantería, vertido de basuras...). Las excavaciones no revelaron el sistema defensivo del castro-más allá de los muros de aterrazamiento.

La ladera W (fig. 3) muestra un espacio que fue ocupado de manera muy intensa durante siglos. Esta ocupación queda reflejada de diferente forma en el registro arqueológico: El período cronológico mejor conservado es el comprendido entre los siglos II a. C. - I a. C., es decir, los momentos finales de la Segunda Edad del Hie- 


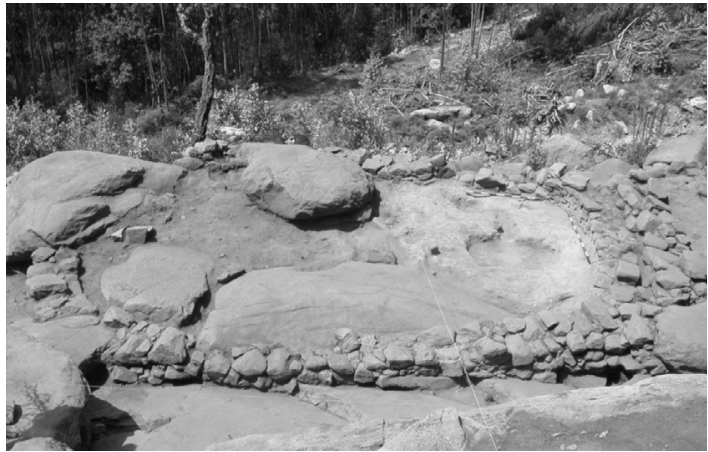

Figura 4. Cabaña D, construida a mediados del s. II a.C.

rro. De este período son las cabañas de planta oval que mantienen una orientación N-S y que se disponen de manera paralela al muro de la terraza que circunscribe todo este espacio (cabañas C, D y E y aterrazado I). Evidentemente la construcción del aterrazado es anterior al momento de construir las viviendas, como lo indica el hecho de que éstas se construyesen perfectamente alineadas al muro de aterrazamiento o, como en el caso de una de las viviendas, contra el mismo muro de contención, aprovechando la cara interna de la terraza como pared de la cabaña. A pesar de ser el momento del que quedó más constancia, las cabañas de este período conservan poco más que el nivel de cimentación, y una vez excavadas muestran un único nivel de uso. Destaca el hecho de que el espacio en el que se construyeron las viviendas mostraba originalmente una superficie completamente irregular, con múltiples afloramientos rocosos que dificultaban la construcción de viviendas. Este aspecto llevó a una ingente labor de acondicionamiento del espacio en forma de potentes depósitos de relleno, tanto en el interior de las cabañas como en el exterior. En dichos rellenos aparecieron materiales anteriores a la gran reforma del siglo II a.C., pertenecientes al Hierro Antiguo (VIII-V a.C.) y a la Segunda Edad del Hierro en su Fase II local (s. IV-II a.C.).

La estructura que mejor conserva restos de esta ocupación es la cabaña de planta oval (de muros de granito), que denominamos cabaña D (fig. 4). Posee unos $6 \mathrm{~m}$ de longitud en su eje N-S por unos $4 \mathrm{~m}$ en su eje E-W, con una pequeña estancia aneja en su lado $\mathrm{N}$ de unos $2 \mathrm{~m}$ en su eje N-S. Conservaba los restos de un nivel de uso (UE088), vinculado a los restos de un pavimento de granito meteorizado (UE129) y a dos pequeños hogares muy desmantelados. Por debajo se identificaron numerosos niveles de relleno destinados a regularizar una superficie habitable. Por encima de esta estructura y reaprovechando parte de los muros, se identificó la superposición de un muro recto vinculado con la ocupación más tardía, pero del que no quedaban niveles asociados. Este segundo momento de ocupación que se puede adscribir al siglo
I d. C - es decir, al comienzo de la ocupación romana efectiva de la zona-queda reflejado en las cabañas de planta cuadrada y con una orientación E-W (cabañas A, B y superposición D). Este segundo momento se superpone en algún punto a las cabañas o estructuras de la fase anterior. La construcción de nuevas viviendas explica la alteración de los estratos preaugusteos.

El estado de conservación del nivel julio-claudio es desigual, en algunas zonas está desaparecido casi por completo: básicamente se puede identificar por la posición topográfica en la que se encontraban las construcciones, en puntos muy próximos a la ruptura de pendiente. En otros casos la conservación es mejor: algunos lienzos de los muros tienen suficiente altura como para conservar la entrada como en la cabaña A, que es una vivienda cuadrada de muros de granito, de unos $5 \mathrm{~m}$ de lado. En esta cabaña (fig. 5) se identificó un único nivel de ocupación (UE122) de época julio-claudia, vinculado a un pavimento de granito meteorizado (UE149) y a dos hogares de piedra, que definen claramente un área de actividad doméstica.

Además de estos dos momentos claramente identificados, aparecieron indicios de ocupaciones anteriores pero que no están asociadas a ninguna estructura, y que únicamente quedan reflejadas por la presencia de materiales diagnósticos, principalmente cerámicas, que se pueden relacionar con estos períodos. Así, se documentaron elementos adscribibles a los siglos IV-III a. C., que aparecieron en la excavación pero sin vinculación directa con ninguna estructura, únicamente en el espacio F. Aquí se identificaron restos muy desmantelados de posibles estructuras (un pequeño muro de piedra y una hoguera) relacionadas con este período, pero que aparecen fuertemente alterados por los bloques graníticos que cayeron de la parte superior. Se trata de un espacio delimitado por afloramientos graníticos que pudo haber funcionado como espacio de almacenaje o como depen-

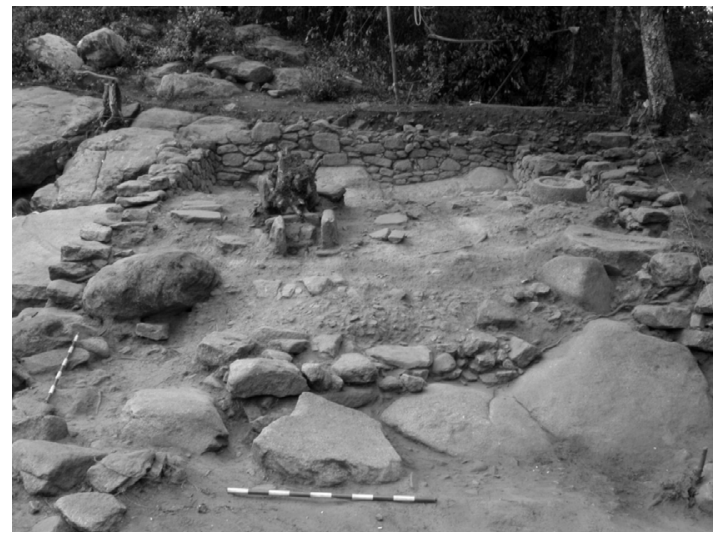

Figura 5. Cabaña A, de época augustea. 
dencia aneja. Por lo que se refiere a los materiales de la Primera Edad del Hierro, éstos fueron encontrados bien en la capa vegetal, bien en los depósitos basales, rellenando las grietas, lo que demuestra la ocupación del sector residencial de la ladera oeste desde inicios del Hierro Antiguo-los materiales están escasamente rodados y tienen gran tamaño.

Finalmente se identificó una reutilización tardía de la ladera $\mathrm{W}$, que responde a un uso muy concreto: el enterramiento de un tesorillo de monedas de bronce de los siglos IV- V d. C. La única estructura relacionada con este episodio es negativa: el hoyo excavado en la tierra para esconder los numismas.

En la ladera E la fuerte pendiente impidió cualquier ocupación de carácter habitacional. Sin embargo, es patente la presencia antrópica, contrariamente a lo que se podía suponer en un principio debido al fuerte desnivel. Los resultados de la excavación indican que en esta zona se desarrolló una notable actividad cotidiana no residencial.

La primera actividad identificada fue una importante labor de cantería (UE023). La topografía del monte sobre la que se asienta el castro resultó determinante en la configuración del poblado. El castro se asienta sobre un espolón muy estrecho, en el que resulta difícil encontrar espacios amplios y llanos que permitan la construcción de las viviendas. Por tal motivo, fue fundamental la construcción de pequeñas zonas aterrazadas en las que poder acondicionar espacios de habitación. Para erigir tales terrazas, se desarrolló una intensa actividad de cantería en la ladera este del monte. Los resultados de la excavación indican que dicha ladera del monte se hallaría desprovista de vegetación, lo que facilitaría los trabajos de extracción de piedra.

Se documentaron además los restos de un canal, anteriores a la actividad extractiva. El canal podría estar relacionado con la evacuación de aguas desde las cabañas de la parte alta del monte. Conviene tener en cuenta que esta estructura apareció a escasa distancia de dos de las cabañas excavadas por Losada Diéguez (1927). El canal se encontraba afectado en uno de sus extremos por las actividades de cantería.

Posteriormente se abandonó la extracción de piedra en la ladera este y el espacio se amortizó como basurero (UE012). Se identificó un conchero de carácter colectivo (fig. 6), localizado extramuros y conformado por diferentes especies de conchas (almeja, mejillón, lapa, ostra, navaja...), así como numerosos restos faunísticos (bovino, ovicaprino, porcino y restos de astas de $\operatorname{ciervo}^{2}$ ). Fue en este depósito en donde se documentaron la mayor parte de los materiales arqueológicos.

\footnotetext{
2 Durante el proceso de excavación se recogieron varias muestras del conchero para la identificación de especies (Fernández Rodríguez 2006).
}

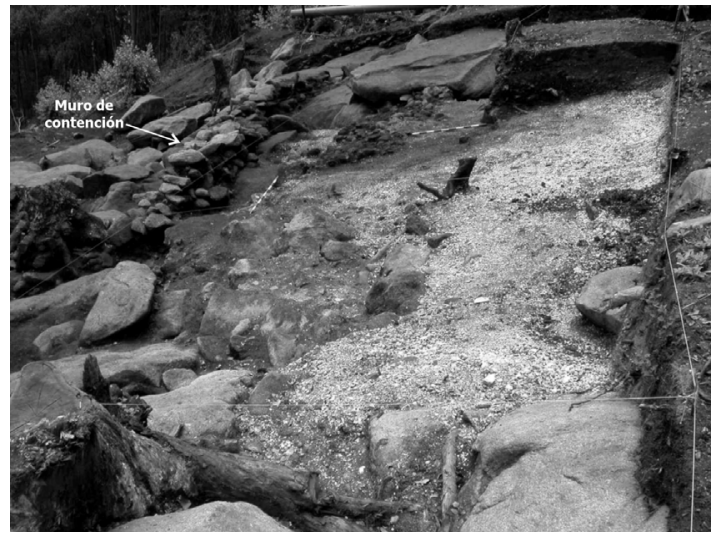

Figura 6. Ladera este: conchero y muro de contención.

En relación al conchero se detectó la presencia de una estructura de contención (UE014). Se trata de un muro de granito de 8 metros de largo y de mala calidad constructiva, del que además apenas se conservan tres hiladas de piedras. El muro se situaba en la parte inferior del vertedero, claramente para impedir el desplazamiento de éste ladera abajo. Es posible que se tratase de evitar que las conchas invadiesen los trabajos de cantería que se desarrollaban en la parte media-baja de la ladera.

La amplitud y potencia del conchero pone de manifiesto la importancia de los recursos marinos para la comunidad. El emplazamiento del castro de Montealegre tiene una clara orientación hacia la explotación del medio marino (principalmente centrada en medios arenosos y rocosos). El momento en el que tales actividades tuvieron lugar es más difícil de precisar. Los materiales documentados en las excavaciones de esta ladera nos sitúan en un amplio abanico cronológico. En depósitos basales y revueltos se ha documentado la presencia de piezas de la Primera Edad del Hierro-entre los que destaca el molde de hacha de cubo localizado en la UE016. La secuencia, sin embargo, llega hasta inicios del siglo I d.C. No obstante, parece que el conchero propiamente dicho se generó básicamente durante la Segunda Edad del Hierro, a tenor de los materiales cerámicos. El grueso de las cerámicas coincide, además, con el momento de ocupación principal de la ladera oeste (siglos II y I a.C.).

Respecto a los materiales indígenas recuperados tanto en el conchero como en el sector residencial (González-Ruibal y Rodríguez Martínez 2006), se han documentado todos los tipos cerámicos característicos del siglo VIII al I a.C. en la región de las Rías Bajas (cf. Rey 1990-91) y más en concreto en la subregión de la Ría de Vigo (González-Ruibal 2005, fig. 23) (fig. 7). La secuencia tipológica acusa un marcado cambio entre la Primera Edad del Hierro (s. VIII-V a.C.) y la Segunda 


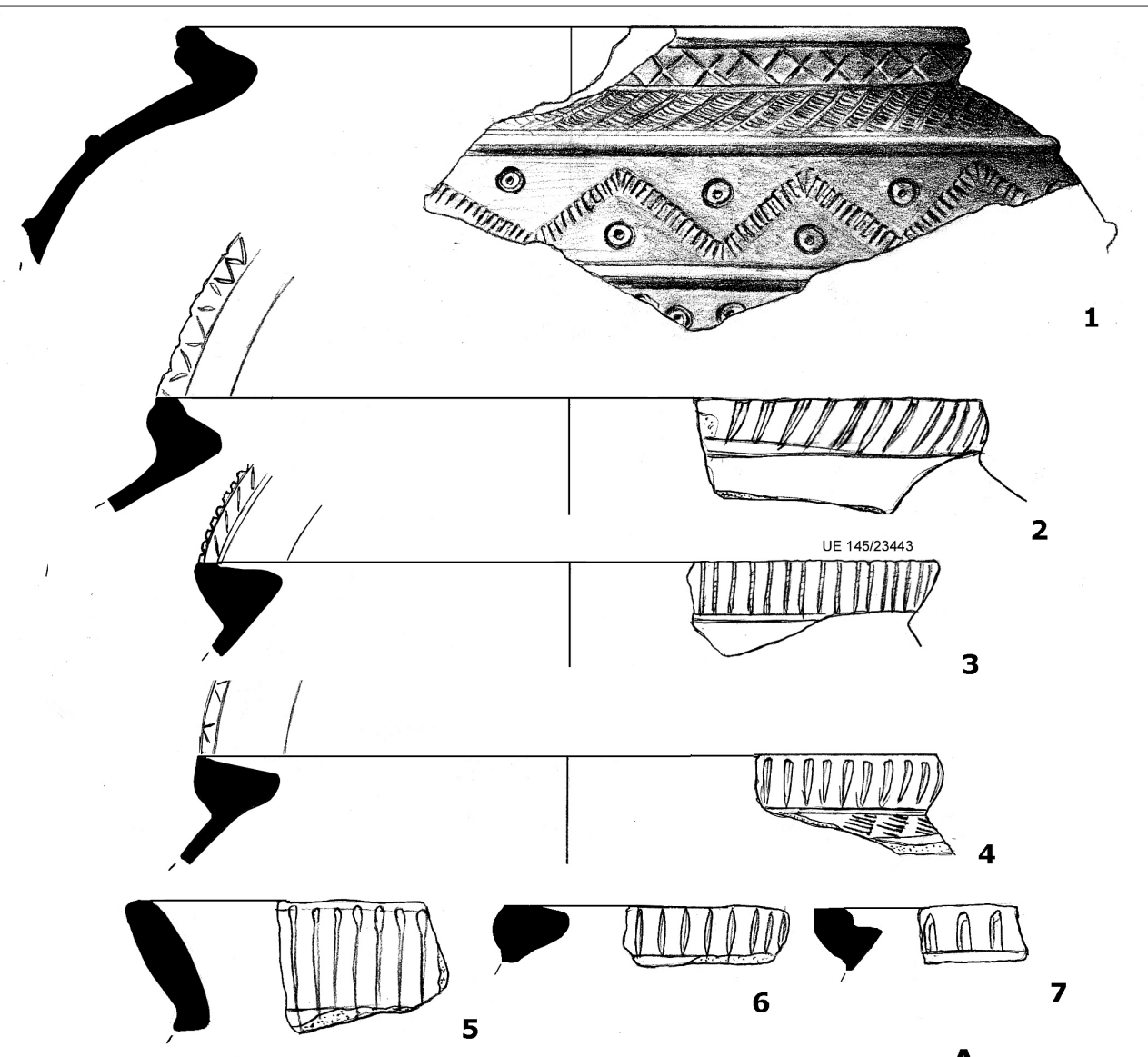

A
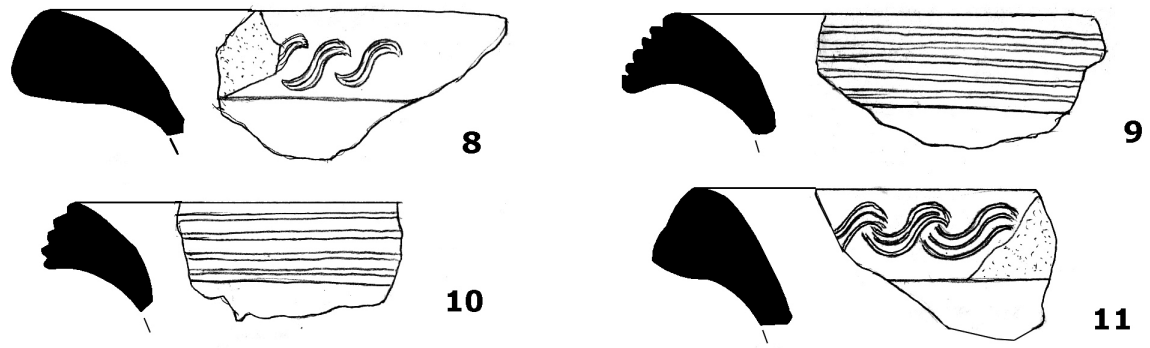

11
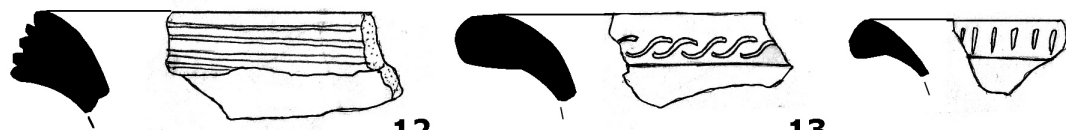

13

14

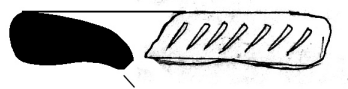

12

15
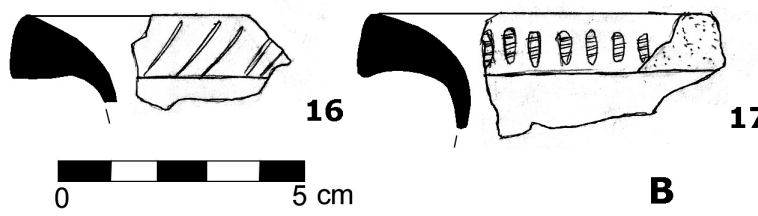

B

Figura 7. Cerámica indígena: mediados del siglo II a.C. - inicios del s. I d.C. Bordes tipo Vigo. (A) Cerámica indígena: siglo IV a.C. - mediados del s. II a.C. Bordes tipo Cíes. (B) 


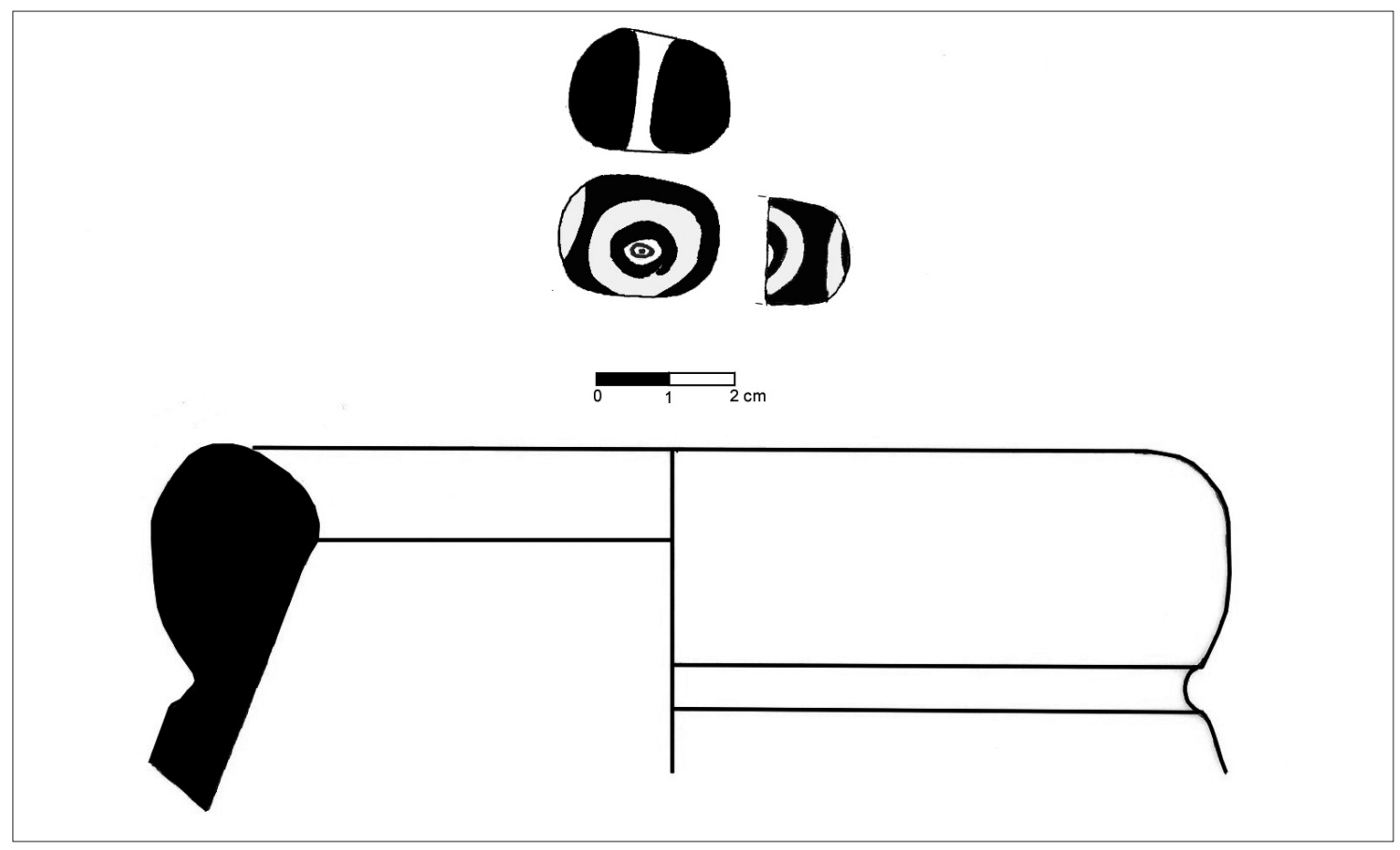

Figura 8. Cuenta oculada de pasta vítrea y borde de ánfora Mañá-Pascual A4.

Edad del Hierro (IV-I a.C.), con una transformación menos marcada, pero obvia, a finales del segundo período-mediados s. II-I a.C. a mediados del siglo I d.C. (Fase III de la Cultura Castreña del Noroeste). Además de una nutrida y variada colección de cerámica, Montealegre ha proporcionado una importante cantidad de fíbulas en excelente estado de conservación, la mayor parte de las cuales, por desgracia, aparecieron revueltas en el conchero. Entre los tipos más antiguos localizados se encuentran varios ejemplares de mesa, conocidas como Sabroso/Santa Luzia en el Noroeste (s. V-IV a.C.) y un pequeño fragmento de una fíbula de doble resorte (s. VIII-V a.C.). Por lo que respecta a la Segunda Edad del Hierro, y más concretamente al período que coincide con las importaciones aquí estudiadas, se han recuperado diversas fíbulas de pie vuelto, entre las que destaca un magnífico ejemplar de fíbula transmontana procedente del sector residencial.

\section{LAS IMPORTACIONES PÚNICAS (S. V-III A.C.)}

Debido a la deficiente conservación de los niveles anteriores a mediados del siglo II a.C. existen muy pocos materiales de importación que se puedan datar con seguridad antes del fin de la Segunda Guerra Púnica. Es muy posible que algunos fragmentos de cerámica a torno tanto de la zona de habitación como del conchero pertenezcan a esta fase. A ella corresponde sin duda una gran cuenta oculada de pasta vítrea localizada en el sector residencial—de color azul ultramar, azul prusia, amarillo y blanco-y dos bordes de ánfora Mañá-Pascual A4 (conchero) (fig. 8). El fragmento mejor conservado corresponde a un modelo T-11.2.1.4, producido en la zona del Estrecho de Gibraltar entre mediados del siglo V a.C. e inicios del siglo IV a.C. (Ramón 1995, 236). Este modelo de ánfora aparece en otros castros de las Rías Bajas con funciones de emporion, como A Lanzada (Noalla) y Punta do Muiño de Vento - Museo do Mar (Alcabre, Vigo), este último situado en la orilla opuesta de la ría de Vigo (González-Ruibal 2004; Suárez Otero 2004). Este tipo de recipientes marcan el horizonte de llegada de los navegantes púnicos al Noroeste, que se puede datar a mediados del siglo V a.C. (González-Ruibal 2006).

En cualquier caso, esta fase de relaciones comerciales no parece haber revestido especial importancia en el castro a tenor de los restos localizados hasta el momento, en comparación con el siguiente período y en contraste con el vecino castro de Punta do Muiño de Vento (Suárez Otero 2004), donde se han recuperado cientos de fragmentos de Mañá-Pascual A4. No se puede descartar, sin embargo, que en otros sectores del poblado se hayan conservado más restos pertenecientes a este período. 


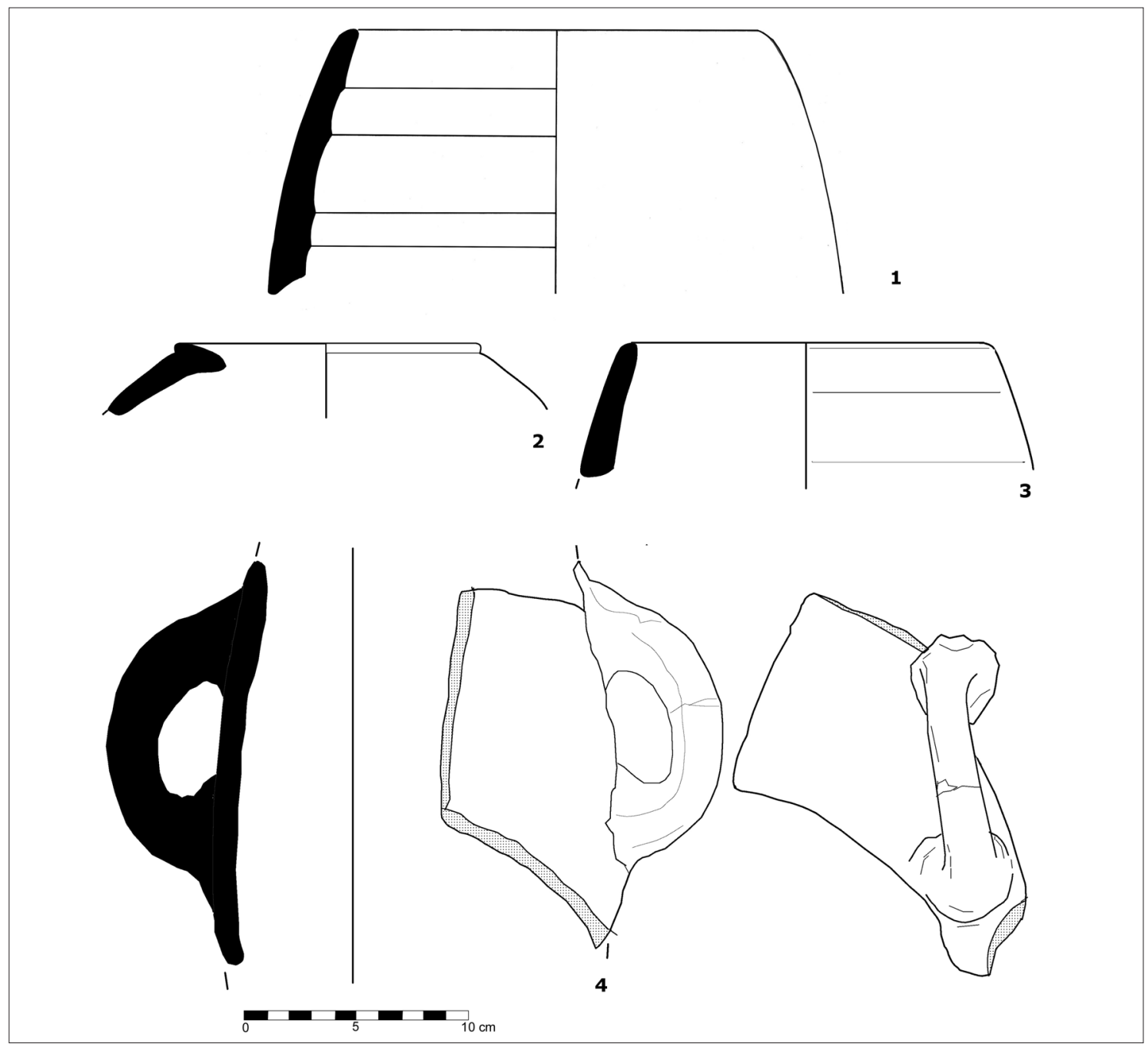

Figura 9. Ánforas Pellicer D.

\section{LAS IMPORTACIONES DEL PERÍODO}

TARDORREPUBLICANO (CA. 150 - 25 A.C.)

Al período que llamamos tardorrepublicano pertenecen un número nutrido de importaciones. Al utilizar esta denominación pretendemos simplemente ofrecer un marco cronológico y político (control del Mediterráneo occidental por la Roma republicana) y no una identificación cultural de los productos—que es variada—ni de los comerciantes, que con toda probabilidad eran púnicos del Estrecho, al menos hasta mediados del siglo I a.C. A esta fase corresponden los siguientes elementos: ánforas itálicas o de tipo itálico; ánforas tardopúnicas; ánforas turdetanas; cerámica común, en su mayor parte fabricada en la Bética; cerámica de transporte pintada; kalathoi procedentes del noreste peninsular; askoi de tradición púnica y cuentas de pasta vítrea monócromas, de color azul marino o de brillo dorado (que aparecen en escaso número).

\section{Ánforas}

\section{1) Ánforas de tradición turdetana}

En primer lugar contamos con algunos fragmentos que se pueden relacionar con las ánforas turdetanas tardías clasificadas como Pellicer D (Niveau de Villedary 2002) (fig. 9). Esta es la primera vez que se reconocen en el norte de la Península Ibérica. Las piezas identificadas son: dos bordes retraídos de pasta jabonosa amarilloanaranjada ( $\mathrm{n}^{\circ} \mathrm{s} 1$ y 3 ), uno de ellos con estrías en el interior muy marcadas; un borde retraído con ligero engrosamiento hacia el interior, con pasta dura y color naran- 
ja-marrón homogéneo $\left(n^{\circ} 2\right)$; y un gran fragmento con asa $\left(n^{\circ} 4\right)$, de pasta dura y color anaranjado homogéneo. Por desgracia todos los fragmentos con forma proceden del conchero. El asa tiene un buen paralelo en Cerro Macareno (Pellicer 1978, fig. 7, no 209), que su excavador data en la segunda mitad del siglo II a.C. Uno de los bordes retraídos (C18805) no muestra engrosamiento hacia el labio, al contrario que muchas ánforas Pellicer D. Sin embargo, éste es un hecho que sí se documenta en algunos contenedores tardíos de esta tipología del Cerro Macareno (Pellicer 1978, fig. 7, $\mathrm{n}^{\circ} \mathrm{s}$ 281, 2001) que se datan en la segunda mitad del siglo II a.C. La misma cronología se puede proponer para el otro borde, más característico de las producciones Pellicer D y que cuenta con un paralelo exacto en la desembocadura del río Arade, en la costa del Algarve (Alves et al. 2001, fig. $\left.2, n^{\circ} 3\right)$. En este yacimiento subacuático aparece el citado contenedor junto a Mañá C2b y Pellicer E (Alves et al. 2001, 242). Las ánforas turdetanas tardías en diversas variantes están bien documentadas desde el siglo III a.C. en la costa meridional portuguesa en sitios como Castro Marim (Arruda 2000, fig. 8-11) y A Rocha Branca (Gomes 1993), entre otros.

\section{2) Ánforas de tradición púnica}

Las excavaciones de 2003/2004 han dado a la luz el mayor lote de ánforas tardopúnicas Mañá C2 divulgado hasta la fecha en el Noroeste peninsular. Se han recuperado 11 bordes (uno de ellos con gran porción de boca, cuello y panza), un asa, un fragmento de cuerpo con arranque de asa y un fragmento de pivote, así como alrededor de un centenar de paredes pertenecientes a este tipo de ánfora (figs. 10 y 11). Las pastas resultan claramente identificables: en todos los casos presentan cocción mixta, con el alma de color más oscuro que la superficie, paredes compactas, lisas y ligeramente ásperas al tacto y desgrasante muy escaso y fino (algún nódulo rojizo, ínfimas partículas de mica). La coloración suele ser ocre o amarillo en la superficie interior y exterior, mientras que el núcleo es de una tonalidad más oscura: naranja, rosa anaranjado o rojo, aunque existen algunos fragmentos de color beige homogéneo $\left(n^{\circ} 9\right)$. La combinación más habitual es amarillo-naranja-amarillo. La mayor parte deben de pertenecer al tipo T7.4.3.3 (Ramón 1995, 206-217), que se fecha, según las últimas propuestas, a partir del 140/130 a.C. (Bernal et al. 2004, 624) y que llegan al 50/30 a.C. (Ramón 1995, 213). Se trata de una versión fabricada en los talleres del Estrecho de Gibraltar de recipientes originales del área de Cartago. Según Ramón $(1995,212)$ su función era transportar conservas de pescado. Un ejemplar tardío es muy probablemente el borde evolucionado (figura $10, \mathrm{n}^{\circ} 1$ ). No obstante, podría proponerse una identificación como T-7.4.3.2 para el fragmento $n^{\circ}$ 9, cuya fecha se centra en la segunda mitad del siglo II a.C., con lo que se solapa parcialmente en el tiempo con la T-7.4.3.3. Existen varios estratos en la zona de habitación (UE 43, 44, 47 y 88) en los que las paredes de ánforas tardopúnicas aparecen asociadas a Dressel 1,

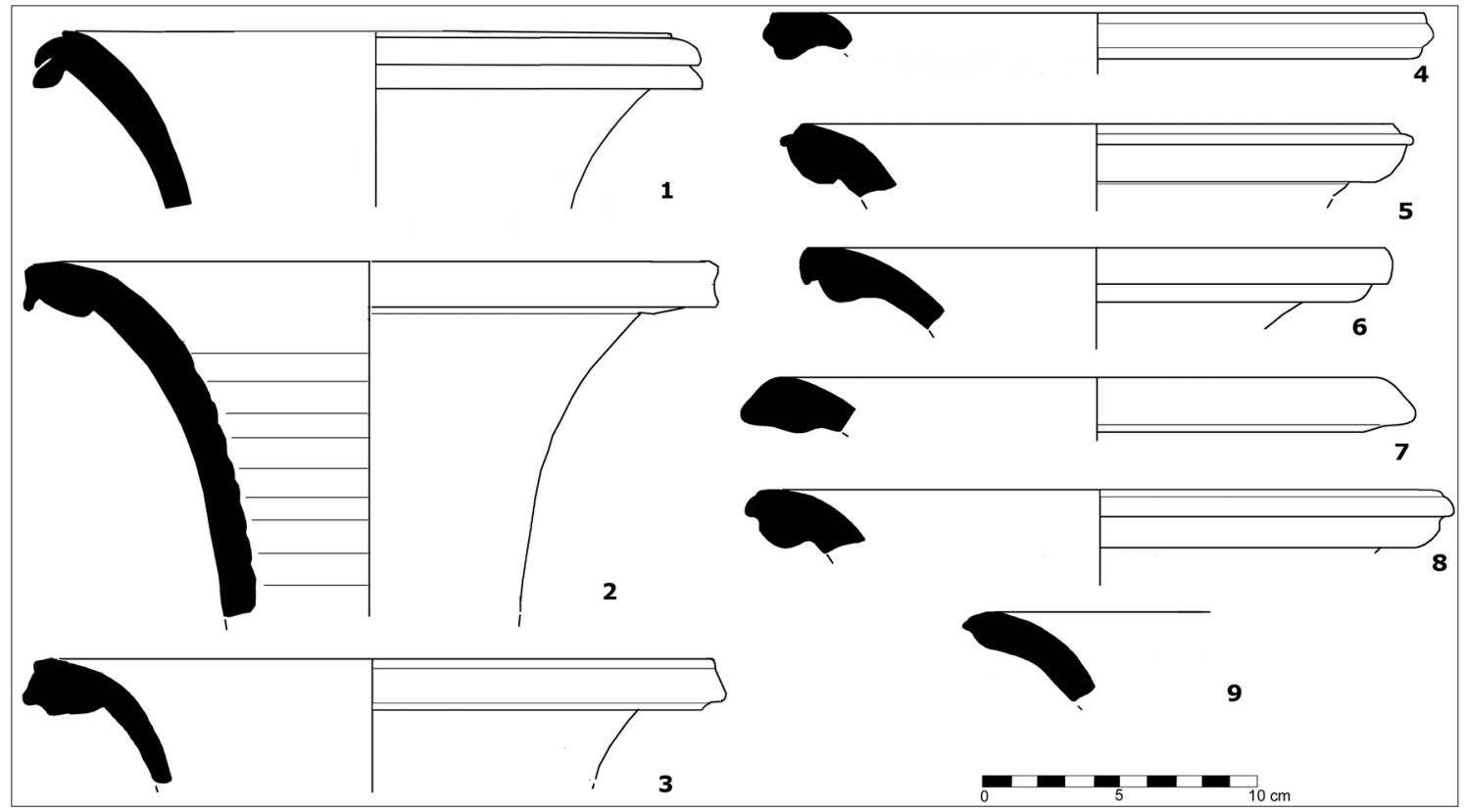

Figura 10. Ánforas Mañá C2b. 


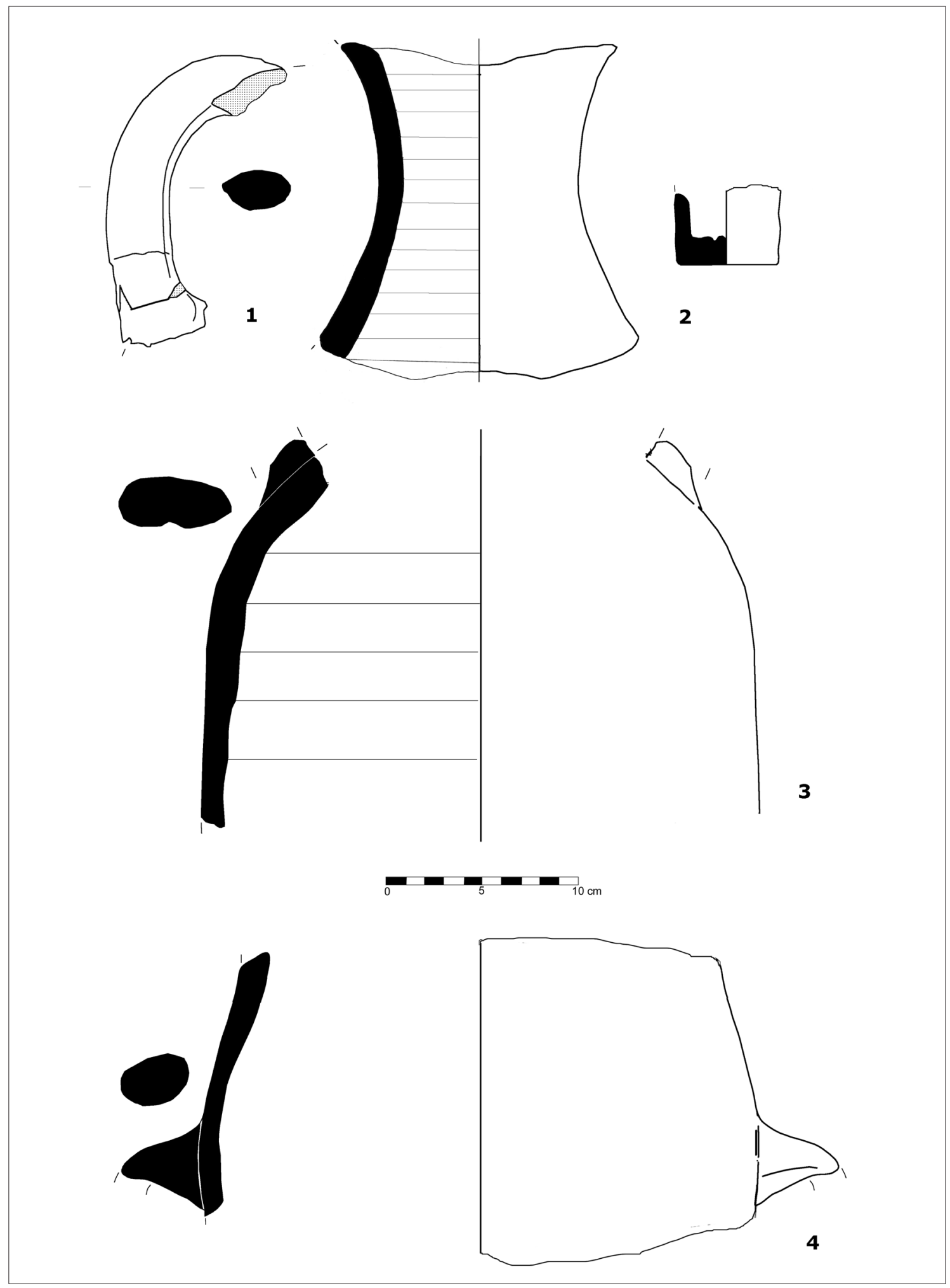

Figura 11. Ánforas Mañá C2b. 


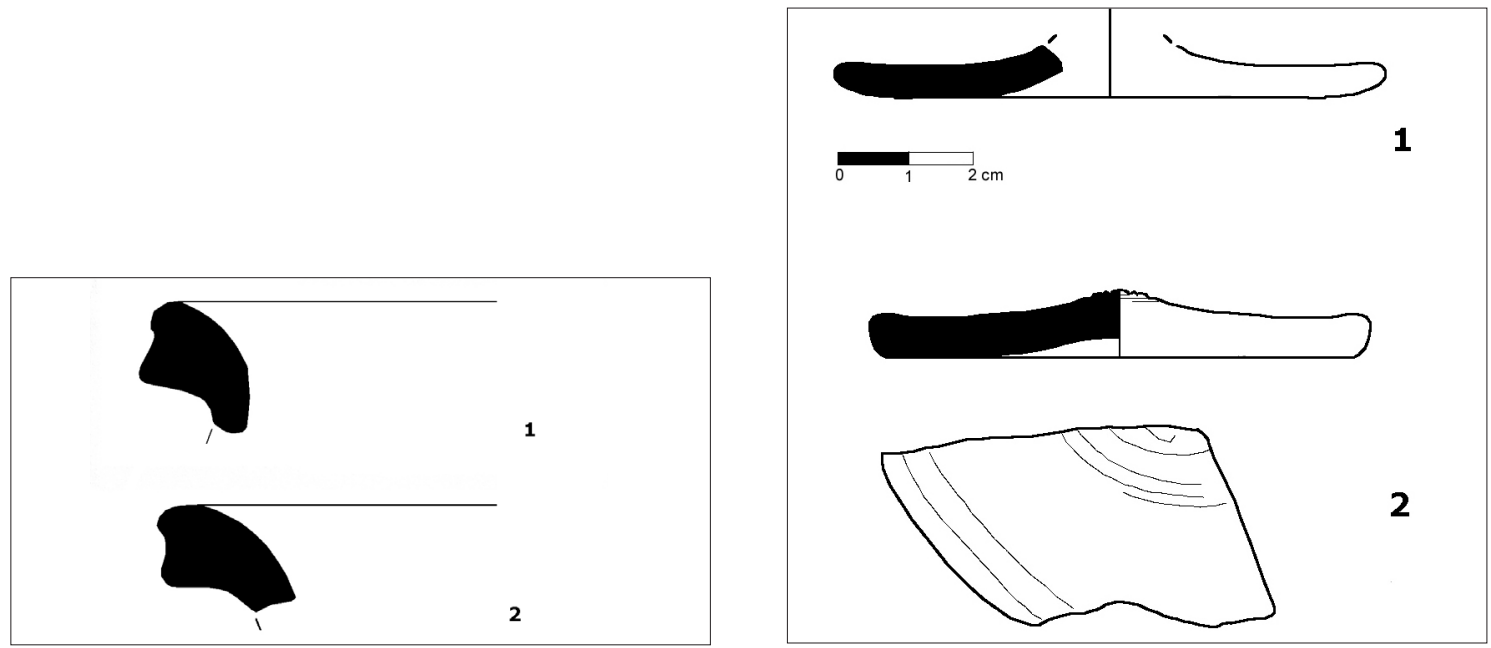

Figura 12. Posibles bordes de Lusitana 1.

Figura 13. Opérculos.

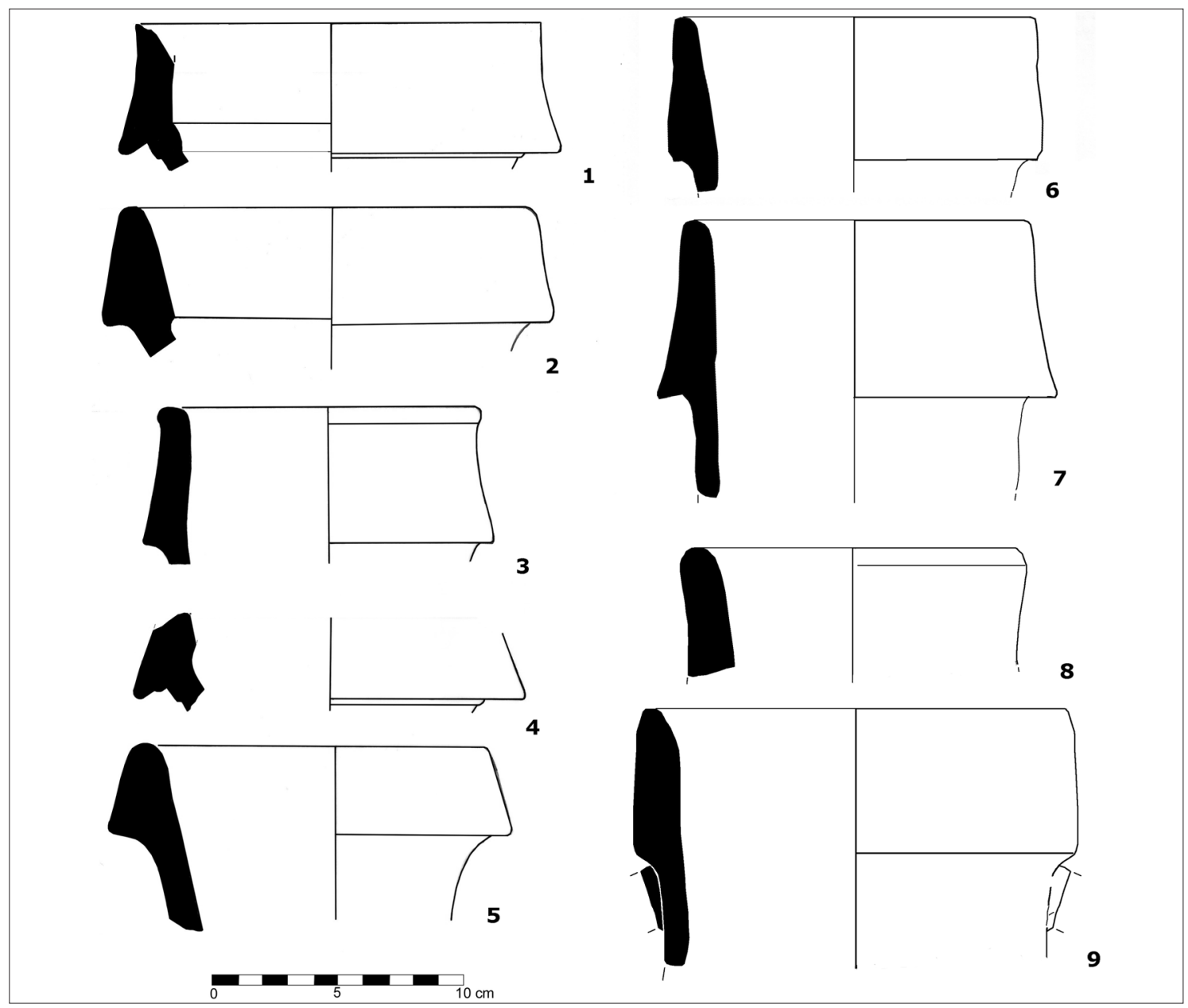

Figura 14. Ánforas Dressel 1. 
algunas de ellas con el característico desgrasante volcánico propio de Campania, lo que reforzaría la impresión, por cronología, de que nos hallamos ante el tipo T-7.4.3.3. Por desgracia, la mayor parte de los bordes (nueve) se recogieron en el vertedero. Un fragmento $\left(\mathrm{n}^{\circ}\right.$ 3) procede de una zona sin estructuras, de un estrato relativamente superficial con materiales variados del siglo IV al I a.C. y otro borde $\left(n^{\circ} 9\right)$ se localizó en la zona alterada entre la cabaña B y la C. En este caso, sin embargo, es muy probable que el borde se relacione con el nivel de uso de la cabaña $\mathrm{C}$, que se data entre mediados del siglo II a.C. y mediados del I a.C. por la presencia de Dressel 1 y kalathoi.

Las ánforas Mañá C2 (Ramón T-7) se están convirtiendo en un tipo bien representado en el Noroeste ibérico, al menos en las Rías Bajas. Hemos señalado su aparición en los castros de Vigo, Punta do Muiño de Vento, Alobre y el embarcadero de O Areal (Vigo), todos ellos en la provincia de Pontevedra (GonzálezRuibal 2004). Recientemente hemos descubierto nuevos ejemplares en el castro de Santa Trega, entre materiales procedentes de las últimas excavaciones de Antonio de la Peña Santos; en A Lanzada (un fragmento de pared característico, de procedencia desconocida, probablemente del Campo da Lanzada) y en el Castro Grande de Neixón (González-Ruibal 2005, 222). Era conocida de antiguo su existencia en la bahía de A Coruña (Naveiro 1982, 69, lám. II, 18-19), lo que corrobora la importancia de Brigantium como puerto comercial a fines de la Edad del Hierro.

Contamos con dos fragmentos de borde procedentes de la zona residencial que se pueden relacionar con las producciones púnicas (fig. 12). El primero de ellos se recogió en la UE 88, que corresponde al nivel de uso de la cabaña D (donde se han localizado paredes de Mañá C2b y Dressel 1). La pasta recuerda a algunas producciones púnicas tardías: color gris claro a rosado, desgrasante muy fino y escaso (mica, alguna intrusión de cuarzo), pasta compacta, jabonosa, con superficies ásperas al tacto. Es posible que se trate de la Lusitana 1, una rara forma tardopúnica característica del litoral portugués. Alves et al. (2001, fig. 6, $\mathrm{n}^{\circ} 31$ ) ofrecen un buen paralelo, procedente del río Sado. Es precisamente en los alrededores de Alcácer do Sal, en este antiguo poblado o en la vecina Salacia, donde se fabricaron las Lusitana 1, aparentemente para envasar conservas de pescado (Diogo 1996). Este autor las considera afines a las Mañá-Pascual A4. Alves et al. (2001, 250-251) datan el contenedor, con interrogantes, en época augustea. Sin embargo, su relación con las producciones púnicas aconseja unos orígenes anteriores. En nuestro yacimiento aparece en un nivel datado entre mediados del siglo II a.C. y mediados de la siguiente centuria.

En relación con las ánforas tardopúnicas debemos mencionar los opérculos (fig. 13). Han aparecido tres piezas bien conservadas, en pasta jabonosa, color amarillo-nápoles claro homogéneo y con desgrasante fino de mica y cuarzo. La cronología habitual para estas piezas es el siglo II y I a.C. Aparecen siempre en asentamientos "con una fuerte presencia o influencia púnica" (Izquierdo et al. 2001, 157). En los niveles del siglo II-I a.C. de Lixus encontramos buenos paralelos (Izquierdo et al. 2001, fig. 2, 21-23), así como en Malta, entre el 100 a.C. y el 50 d.C. (Sagona 2002, forma V: 1b) y en Málaga en los niveles púnicos (Gran-Aymerich 1991, Fig. 67, nº 14-15). Dos de ellas proceden del conchero y una tercera $\left(n^{\circ} 2\right)$ de un nivel revuelto de la zona de habitación.

\section{3) Ánforas itálicas}

Las ánforas Dressel 1 a-c (fig. 14) aparecen representadas por nueve bordes, un pivote y un número difícil de determinar de paredes, aunque sin duda superan el centenar. Se han recuperado tres bordes de ánfora Dressel 1c. Dos bordes de Dressel 1c son de fabricación campaniense (n's 6 y 7), como revela su abundante desgrasante volcánico, pero predominan los de fabricación bética. La mayor parte de las formas aparecieron en el vertedero. No obstante, el pivote, aparentemente de fabricación bética, apareció en el nivel de uso de la cabaña $\mathrm{D}$ y en la cabaña $C$ han aparecido un borde de Dressel $1 \mathrm{c}\left(\mathrm{n}^{\circ} 7\right)$ y otro de una posible Dressel $1 \mathrm{~b}\left(\mathrm{n}^{\circ} 8\right)$. Casi todos los bordes conservan una aguada blanquecina al exterior, característica de estas producciones. Además, del sector residencial, especialmente de las casas $\mathrm{C}$ y $\mathrm{D}$, proceden varias paredes de ánfora que por su pasta característicarojo intenso homogéneo, con escaso desgrasante de ínfimo calibre-se pueden identificar con las producciones anfóricas de la zona etrusca. En otros yacimientos del Noroeste se han localizado ánforas itálicas de Campania y Etruria, como en la Campa Torres, Gijón (Carreras 2001, 390). En el Noroeste, la Dressel 1c es, concretamente, el más habitual de los subtipos de esta tipología. Aparece tanto en los grandes oppida del sur, como Santa Trega (Peña Santos 1985-86) como en los castros asturianos: Campa Torres (Maya y Cuesta 2001) y Arancedo. En las dragas del puerto de la antigua Brigantium (A Coruña) se ha localizado un número notable de Dressel 1c (Naveiro 1982, 67, lám. I), que aparecen asociadas, como señalamos, a Mañá C2 y a cerámica campaniense (Naveiro 1982, 63). Dressel 1 itálicas en buen número y cerámica campaniense aparecen en el emporio indígena de Torres de Oeste, en un estrato de la primera mitad del siglo I a.C. (Naveiro 1995, 73). Se trata de un centro comercial situado en la desembocadura del Ulla que controlaba el comercio hacia el interior de Galicia. En la propia Península do Morrazo donde se enclava Montealegre se ha documentado por ahora este tipo de ánfora en el castro de Monte do Facho. Un hombro de Dressel 1 apareció en un suelo de ocupación de una cabaña circular 


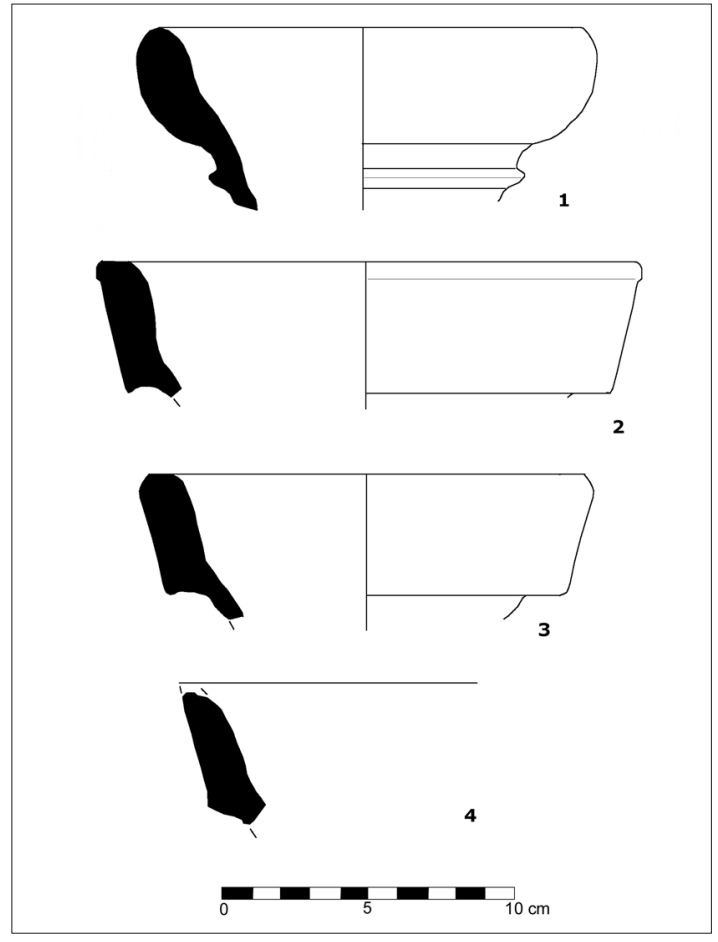

Figura 15. Ánfora LC 67 (1) y Haltern 70 arcaicas (2-4).

sellado por un nivel posterior del s.I a.C. / d.C. y cubriendo uno del siglo IV-III a.C. ${ }^{3}$ La cronología, por lo tanto, sería equivalente a la del área de habitación de Montealegre donde se recuperaron las piezas mencionadas.

La cronología de las Dressel 1 se sitúa entre mediados del siglo II a.C. y mediados del siglo I a.C. Coinciden, por lo tanto, cronológicamente, con las T-7.4.3.3: una coincidencia temporal que se manifiesta en numerosos yacimientos tardorrepublicanos del Mediterráneo occidental (cf. Díaz 2000). A partir de mediados del último siglo antes de la Era las Dressel 1 comenzarán a ser suplantadas por las ánforas Haltern 70, procedentes de los alfares béticos.

Los últimos tipos de ánfora que consideraremos en el comercio preagusteo son las Haltern 70 antiguas y las denominadas LC 67, que se datan en 75-25 a.C. (fig. 15, $\mathrm{n}^{\circ}$ 1). Un borde de LC 67 bien conservado apareció en una misma bolsada del conchero junto a una Dressel 1c de posible fabricación gaditana $\left(\mathrm{n}^{\circ}\right.$ 9) y tres bordes de Haltern 70 antiguos (Fig. 15, nº 2-4). La pasta de estas ánforas es más depurada y con un desgrasante mucho más fino y menos abundante que los de las producciones de época augustea y posterior. La superficie es lisa y

\footnotetext{
3 Campaña de mayo-junio de 2004 dirigida por José Suárez Otero y Thomas Schattner.
}

áspera al tacto y el color amarillo-ocre al exterior con el alma rojiza—características que recuerdan a las producciones de T-7.4.3.3 de Montealegre. Morfológicamente, es notable su semejanza en dos casos con las Dressel 1c, especialmente por la pestaña que sobresale hacia abajo: buenos paralelos se encuentran en Brácara (Morais 2004a, 554, fig. 8). Las muestras más antiguas de producción de Haltern 70 en la Bahía de Cádiz se datan a mediados del s. I a.C. (García Vargas 2000, 67, 70) y el origen para este tipo podría llevarse hasta el 75 a.C., con lo que coincidiría con las LC 67. En Tarraco, las LC 67 aparecen en contextos de 50 - 25 a.C. (Díaz 2000); en Málaga se localizan juntas Haltern 70, LC 67, las últimas T-7.4.3.3 y las primeras Dr. 7/11 (cf. Gran-Aymerich 1991, fig. 81); en Cádiz (Lagóstena 1996, 166-168), Lixus (Izquierdo et al. 2001, fig.3-4), Tarraco (Díaz 2000, figs. 58-60) y las Baleares (Toniolo y Fayas 2002, 707-709) se documentan juntas Dressel 1c, Haltern 70 y LC 67, al igual que en Montealegre. En Lomba do Canho, donde las LC 67 aparecen asociadas a Haltern 70 muy semejantes a las mencionadas y cerámica campaniense (Fabião 1989, 65-69; Nunes e Fabião 1989, fig. 7), hay que considerar una datación cesariana, en torno a mediados del s. I a.C. Fabião incluye entre las Dressel 1 b de Lomba do Canho dos bordes (Fabião 1989, 58-59, fig. $3,730,871)$ que, al contrario que el resto de los contenedores de este tipo localizados en el yacimiento, carecen de desengrasante volcánico. Es por lo tanto razonable pensar que se trata realmente de Haltern 70. Fuera de la Península Ibérica, este contenedor aparece en niveles datados entre el 50-30 a.C. (Fabião 1989, 65). En Galicia, la LC67 está muy bien representada en el castro de Santa Trega (Peña Santos 1986), donde aparece con Dressel 1, Haltern 70 y campaniense.

\section{Cerámica común}

Llama la atención el número relativamente elevado de vasijas pertenecientes a producciones de cocina y mesa, frente a la ausencia de materiales finos (barniz negro, copas, platos pintados). La mayor parte de los fragmentos se corresponden a ollas de dimensiones reducidas. Asimismo se han identificado un cierto número de fragmentos pertenecientes a jarros, ungüentarios y morteros.

\section{1) Ollas y tazas (fig. 16)}

Todos estos recipientes se caracterizan por su pasta blanda, amarillo-blanquecina a anaranjada clara, con muy escaso y fino desgrasante (mica y cuarzo). Las similitudes tanto formales como tecnológicas hacen pensar en su pertenencia a un mismo taller o grupo de talleres. Es posible, además, que los morteros a los que haremos mención más adelante también se fabricaran en 


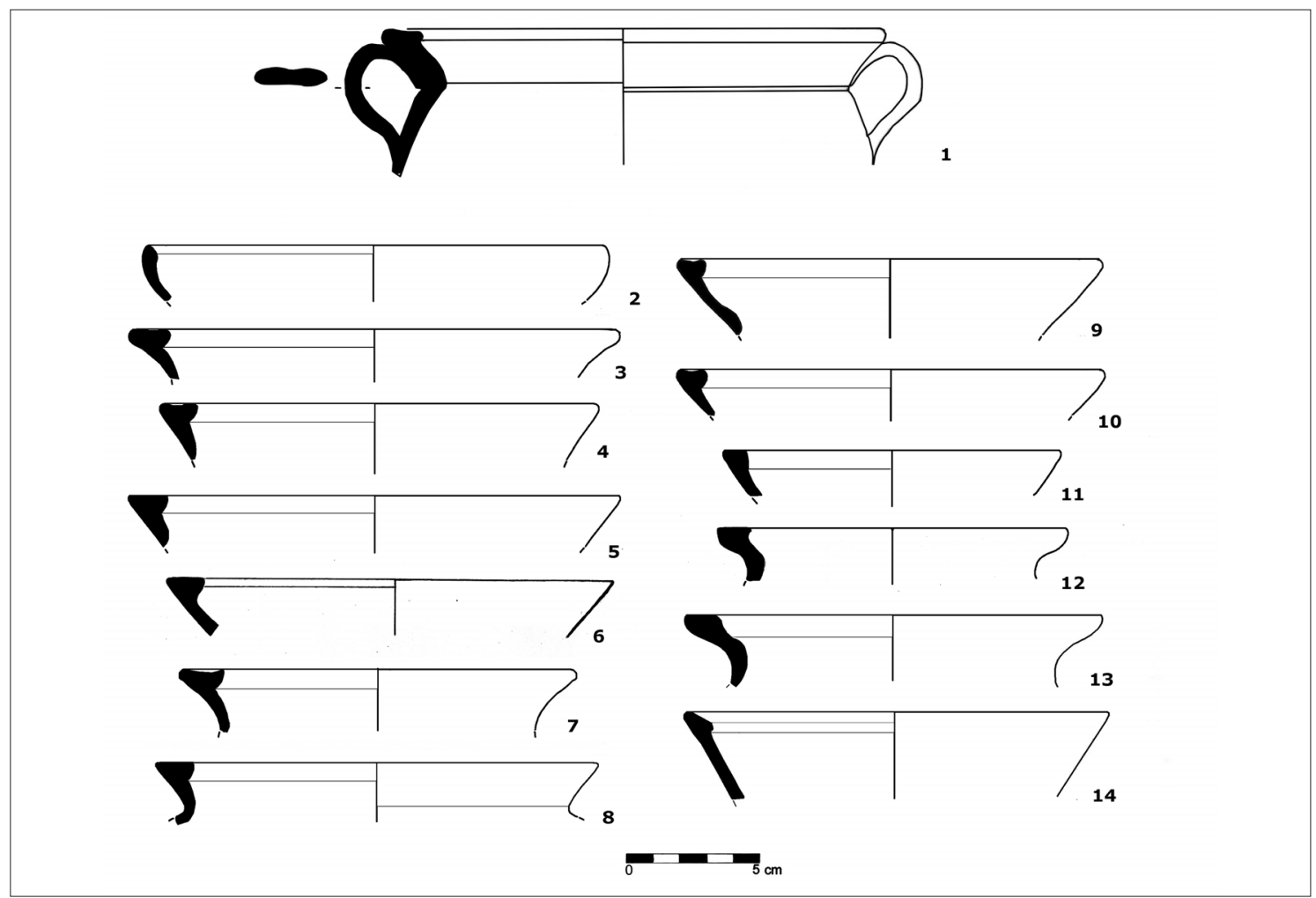

Figura 16. Cerámica común tardorrepublicana de plasta amarillo Nápoles. Bordes.

los mismos centros, dadas su afinidades técnicas. Las ollas, jarras y morteros son muy semejantes, incluso idénticos, a las del grupo de céramiques blanc jaunatre de Conímbriga (Alarcão et al. 1976, 71 ss). La descripción de las pastas que nos ofrece Alarcão y colaboradores coincide con las de Montealegre: color blanco-amarillento, pasta muy poco compacta, que deja marcas en los dedos, y desgrasante muy fino y escaso, con partículas de mica y minúsculos fragmentos de cuarzo (Alarcão et al. 1976, 71-72). Tanto en Conímbriga como en Lixus (Izquierdo et al. 2001) estos materiales aparecen en muy reducido número y se consideran importaciones. El hecho de que los mejores paralelos para estos materiales se encuentren en el litoral marroquí y portugués aconseja un origen atlántico para estas producciones. Es posible que se fabricasen en ambientes de tradición púnica. Se propone la siguiente tipología:

1. Bordes con resalte posterior (fig. 16, $\mathrm{n}^{\circ} \mathrm{s} 1,3-10$ ).

1.1. Bordes apuntados y labio plano.

1.2. Bordes redondeados bífidos.

1.3. Bordes mixtos,

2. Bordes estrangulados (fig. $16, \mathrm{n}^{\circ} \mathrm{s} 11-13$ ).
3. Bordes oblicuos (fig. 16, $n^{\circ} 14$ ).

1.1. Bordes con resalte posterior, apuntados y con labio plano. Estas piezas tienen buenos paralelos en el nivel púnico-mauritano II de Lixus (Izquierdo et al. 2001, fig. 2, 6) y en Conímbriga (Alarcão et al. 1976, pl. 18 , 26), donde aparecen fuera de contexto en los rellenos del foro flavio. Recordemos no obstante que entre los materiales revueltos de este último yacimiento figuran ánforas Dressel 1, Mañá C2 y kalathoi ibéricos, como en Montealegre, y que Conímbriga era un importante castro indígena desde el período orientalizante. La fecha propuesta para el nivel púnico-mauritano II de Lixus se enmarca entre el 80 a.C. y el final del principado de Augusto.

1.2. Bordes redondeados con labio bífido. A este subtipo pertenecen los fragmentos $n^{\circ} 9$ y 10. Tienen cierto parecido formal con los cuencos de borde bífido tardorrepublicanos (Vegas 1973, 43-44, forma 14). Sin embargo, en este caso nos hallamos ante ollas, según demuestra el paralelo de Conímbriga (Alarcão et al. 1976, pl. 18, 25) y de dimensiones reducidas.

1.3. Bordes mixtos. Presentan características de los dos subgrupos anteriores. 


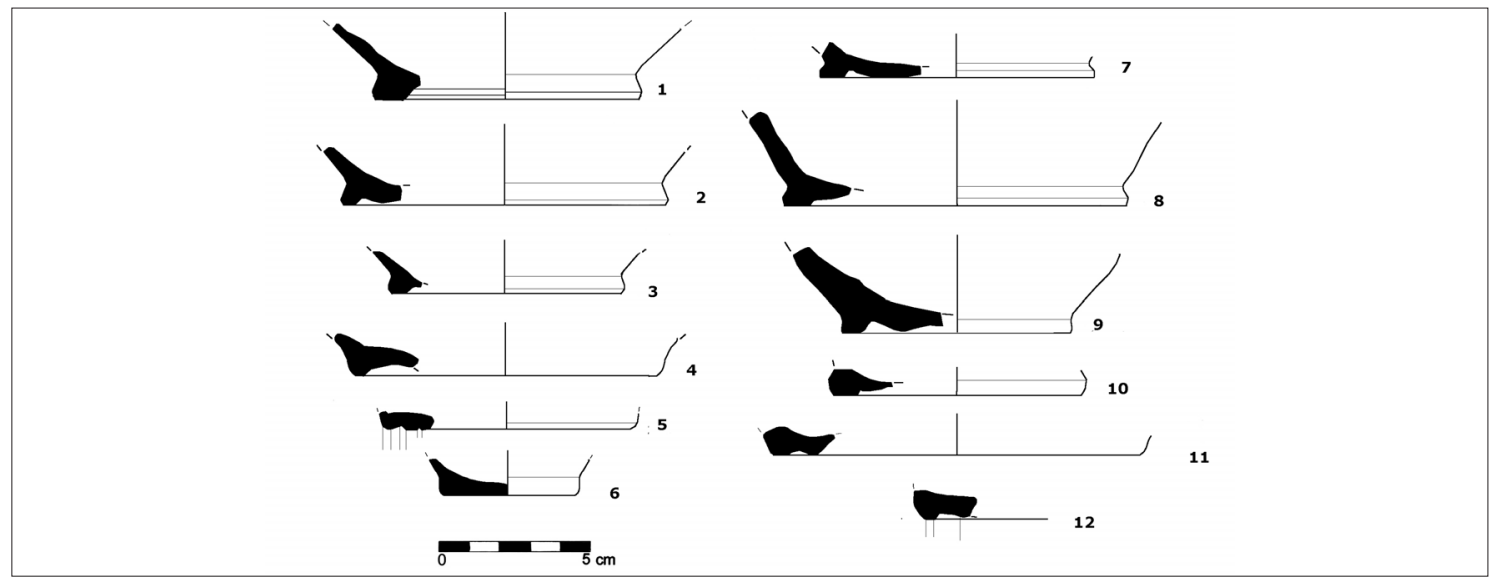

Figura 17. Cerámica común tardorrepublicana de pasta amarillo Nápoles. Fondos.

2. Los bordes estrangulados recuerda a los de algunas ollas púnicas tardías, de los siglos II-I a.C. Existen paralelos aceptables en el norte de África, en Cartago (Hayes 1976, fig. 15, no s 9, 13) y en Leptiminus (Dore y Schinke 1992, 137-139, no 5). En este último sitio este tipo de ollas aparece en contextos de la segunda mitad del siglo II a.C.

3. El borde biselado oblicuo ( $\left.{ }^{\circ} 14\right)$ también cuenta con un paralelo exacto en Conímbriga (Alarcão et al. 1976, pl. 18, 45) e igualmente pertenece a una ollita.

Los bordes biselados con aristas o facetas al interior son muy típicos de todas las producciones de fines del primer milenio antes de la Era en el Mediterráneo, bien sean materiales helenísticos, itálicos o púnicos. Excepto en la cerámica africana de cocina, este tipo de formas tienden a desaparecer a lo largo del siglo I d.C. En Montealegre, paredes de similares características técnicas a los bordes se localizan en estratos del siglo II a.C. y I a.C. No se documentan en cambio en estratos julio-claudios, como lo demuestra el hecho de que en la cabaña A aparecieran Haltern 70 y cerámica común romana de pastas naranjas, pero ni un solo fragmento del tipo al que nos estamos refiriendo. Así pues, se podría aventurar una datación desde mediados del siglo II a.C. hasta inicios de época augustea.

De idénticas características técnicas es una taza en cerámica común procedente del conchero (fig. 15, $\mathrm{n}^{\circ} 2$ ). Recuerda bastante a las producciones mediterráneas de época helenística (s. III - I a.C.), tanto púnicas como itálicas (cf. Campanella 1999, fig. 10: 73-76), pero modelos semejantes llegan al siglo I d.C.

Como sucede con otros materiales, tampoco los bordes de cerámica común han sido recuperados en buenos contextos estratigráficos. La gran mayoría aparecieron en estratos superficiales y revueltos. En estratos que podemos considerar preagusteos se localizaron los bordes $n^{\circ} 13$ (UE 41), en una zona de deambulación (espacio E) cerca del afloramiento rocoso, $\mathrm{y} \mathrm{n}^{\circ} 14$ (UE 62), al norte de la cabaña D. La UE 62 puede homologarse cronológicamente a la UE 88, el nivel de uso de la cabaña $\mathrm{D}$, que se data entre el último tercio del siglo II a.C. y el primer tercio del siglo I a.C. En esta UE han aparecido dos bordes tipo Cíes evolucionados (fig. 7, n ${ }^{\circ}$ s 14 y 16), que habría que datar a fines del siglo II a.C. - inicios del siglo I a.C. El borde que apareció en la cabaña B ( $\left.n^{\circ} 4\right)$ es de cronología menos segura, pero es muy probable que pertenezca también al episodio de ocupación preaugusteo, que fue arrasado para construir una cabaña de planta rectangular: en las cercanías se documentó un borde de Mañá C2b (UE 45, vid. supr.).

La misma técnica y pasta presentan la mayor parte de los fondos identificados (fig. 17). Lo más probable es que se correspondan con las ollas y tazas cuyos bordes acabamos de tratar-así como con los jarros que mencionaremos a continuación. Tres de los fragmentos $\left(\mathrm{n}^{\circ} \mathrm{s}\right.$ 1 y 12) aparecieron en estratos que se pueden datar en el siglo II o inicios del siglo I a.C. en el espacio entre la cabaña D y el muro absidal que se le adosa por el norte. Los demás proceden bien del conchero, bien de estratos superficiales.

Diferente al material analizado por su forma y características técnicas es un cuenco a torno, de pasta gris homogénea, superficie áspera y borde aristado oblicuo (fig. 18). Tiene buenos paralelos entre mediados del siglo II a.C. y fines del s. I a.C. en el Mediterráneo occidental (p.ej. Campanella 1999, fig. 17, 135; Guerrero 1984, fig. 53, 6-9; Gran-Aymerich 1991, fig. 78, nº 17). Cuencos similares, pero de mayores dimensiones, se siguen fabricando en época romana (Alcorta 2001, fig. 75, F2, C4). Procede de un nivel superficial del sector de habitación, con lo que es difícil saber si pertenece al comercio tardorrepublicano o posterior. 


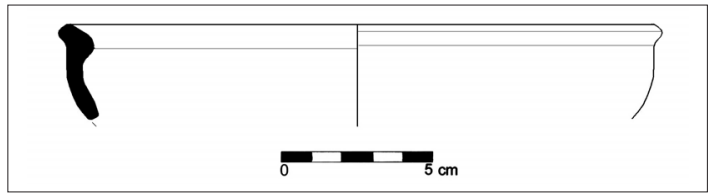

Figura 18. Cerámica común tardorrepublicana de pasta gris.

\section{2) Jarros y jarras}

Pertenecen a jarros de pequeñas dimensiones seis asas y un borde (fig. 19) cuyas pastas resultan muy semejantes a las del conjunto de cerámica común señalado. También pertenecen a jarras dos fragmentos de cuello de cocción mixta y color anaranjado. Todos los fragmentos menos uno (el asa $\mathrm{n}^{\mathrm{o}} 7$ ) aparecieron en estratos superficiales o revueltos (concheros). El asa que sí apareció estratificada lo hizo en un paquete preaugusteo (UE 56), por su posición en la secuencia estratigráfica y por la cerámica indígena asociada. El fragmento más reconocible pertenece al cuello y borde de un jarrito de boca redonda y pasta amarillo-nápoles homogénea. Este tipo de jarros son frecuentes en la segunda mitad del siglo I a.C. e inicios del siglo I d.C. En un nivel augusteo aparecen en Malaka (Gran-Aymerich 1991, fig. 80, $\mathrm{n}^{\mathrm{o}} \mathrm{s} 20-21$ ), en Lixus lo hacen en el nivel púnico-mauri-

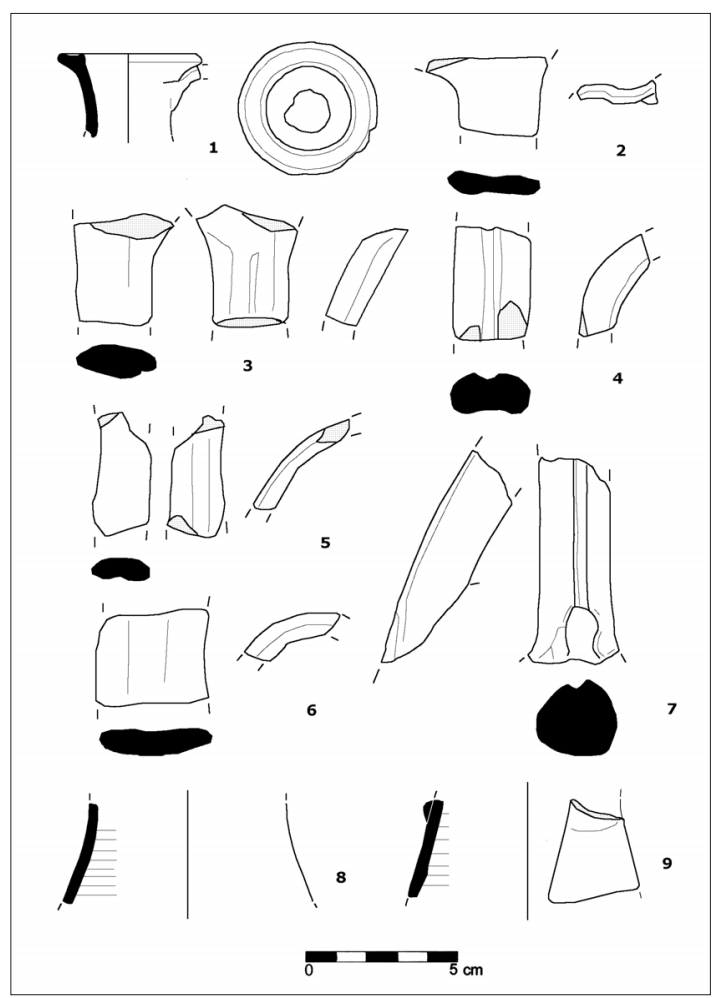

Figura 19. Jarras y jarros tardorrepublicana.

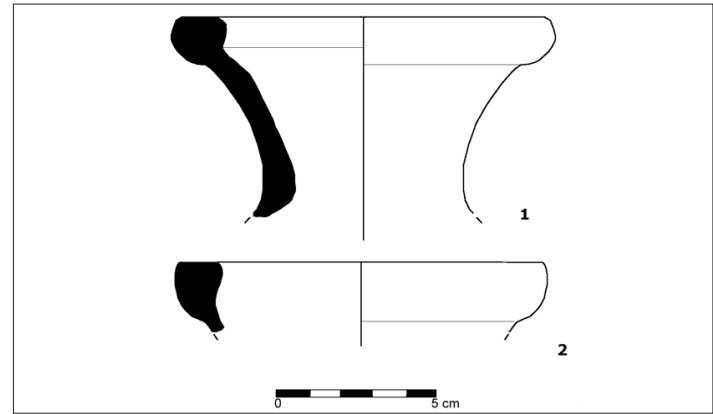

Figura 20. Jarras de boca ancha y pasta blanca tardorrepublicanas.

tano II (Izquierdo et al. 2001, fig. 2, $\mathrm{n}^{\circ}$ 8), mientras que en Conímbriga aparecen en estratos de relleno preflavios (Alarcão et al. 1976, pl. XVIII, $\mathrm{n}^{\circ}$ s 24, 33, 44).

Poseemos además dos bordes de jarras de boca ancha con el borde engrosado (fig. 20). Las jarras de boca ancha son características del mundo púnico entre los siglos IV y II a.C. Los mejores paralelos para nuestra pieza proceden del yacimiento sardo de Monte Sirai (Campanella 1999, figs. 12 y 13): aparecen aquí varias jarras con boca de amplio diámetro y labio engrosado hacia el interior que recuerdan notablemente a nuestra pieza. Se datan en los siglos III-II a.C. El fragmento mejor conservado de Montealegre ( $\left.\mathrm{n}^{\circ} 1\right)$, que además es el único que apareció en contexto estratigráfico (UE 136), posee pasta jabonosa, color blanco sucio homogéneo y desgrasante arenoso y abundante. El color y la pasta recuerdan a las producciones púnicas localizadas en otros castros gallegos. Apareció en el espacio entre la cabaña D y el muro absidal que se le adosa, una zona rica en material de importación. La datación de este estrato es de mediados del siglo II a.C. a mediados del s. I a.C.

\section{3) Ungüentarios (fig. 21)}

Se han recuperado dos fragmentos pertenecientes a ungüentarios. Uno de ellos es una boca de un típico

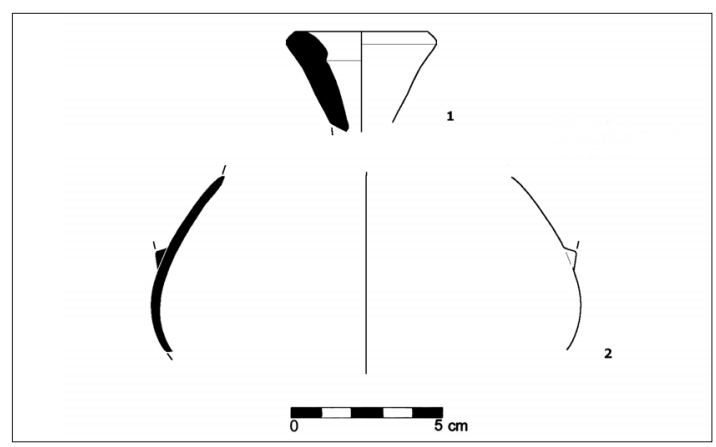

Figura 21. Ungüentarios. 


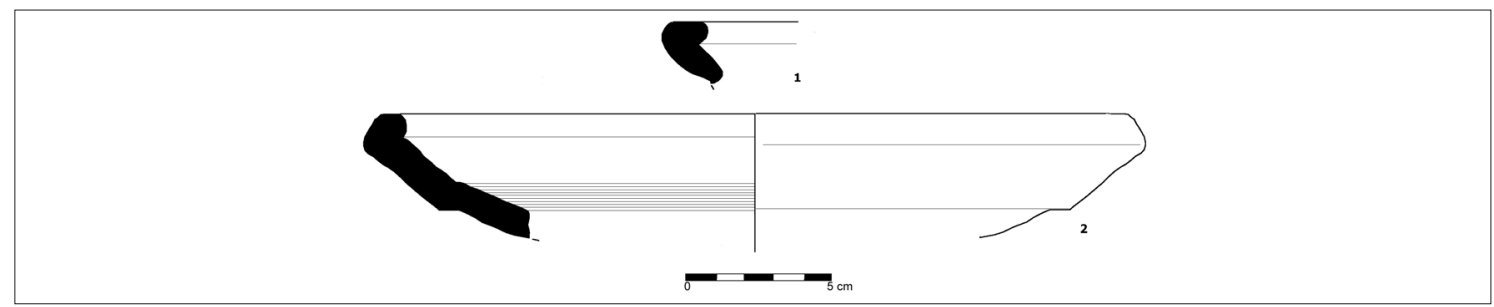

Figura 22. Morteros tardorrepublicanos.

ungüentario fusiforme $\left(n^{\circ} 1\right)$. La cronología amplia para estos recipientes se enmarca entre el siglo IV a.C. y las primeras décadas del siglo II d.C. (p.ej. Sagona 2002, forma IV:1a - VI:1), aunque su popularización se produce durante el siglo II a.C. y desde inicios del siglo I d.C. sufren la competencia de los ungüentarios de vidrio y por lo tanto su número declina. Aparecen en yacimientos púnicos (Cintas 1950, II, 34-36; Almagro 1984, fig. 29), púnico-romanos (López Castro 1995, fig. 40) y romanos (Vegas 1973, 153-155, fig. 58). La otra pieza $\left(n^{\circ} 2\right)$ es un fragmento de panza con arranque de asa de lo que debió de ser una botellita o vaso globular con cuello. Este tipo de recipientes son típicos de fines del s. II a.C. a inicios del I d.C. (p.ej. Sagona 2002, forma V:1c y VI:1).

En el noroeste no se han señalado ungüentarios cerámicos, con la excepción del fragmento de A Lanzada localizado por uno de nosotros (Rafael Rodríguez Martínez), de tipo fusiforme, en la revisión de los materiales de excavaciones antiguas depositados en el Museo de Pontevedra. Su escasez puede deberse a que cuando el comercio mediterráneo se incrementó exponencialmente en la zona, durante el período julio-claudio, los ungüentarios de cerámica se encontraban ya en retroceso frente a los de vidrio. Sin embargo, también habrá que atribuir su escasez a la falta de demanda indígena de perfumes y ungüentos.

\section{4) Morteros (fig. 22)}

Se ha recuperado un fragmento $\left(n^{\circ} 2\right)$ bien conservado de un mortero del tipo IIA de Morais (2004, 568, fig. 3). Su cronología se sitúa entre época tardorrepublicana y de Tiberio y su procedencia bética es bastante segura (Serrano 1995, 231, figs. 4-27). En la fachada atlántica se han documentado, además de en Brácara (Morais 2004), en el castro indígena de Mesas do Castelinho (Alentejo) en niveles tardorrepublicanos (Fabião y Guerra 1994), en Conímbriga, en rellenos del foro de época flavia (Alarcão 1976 et al., 71, 73, pl. XVII, 4) y en el nivel púnicomauritano II de Lixus, datado entre 80 a.C. - 15 d.C. (Izquierdo et al. 2001, 157, fig.2, 9). En Galicia poseemos un paralelo procedente del castro de A Lanzada, descubierto por uno de nosotros (RRM) durante la ya mencionada revisión de materiales. De los dos fragmentos de Montealegre, sólo uno apareció en el sector resi-

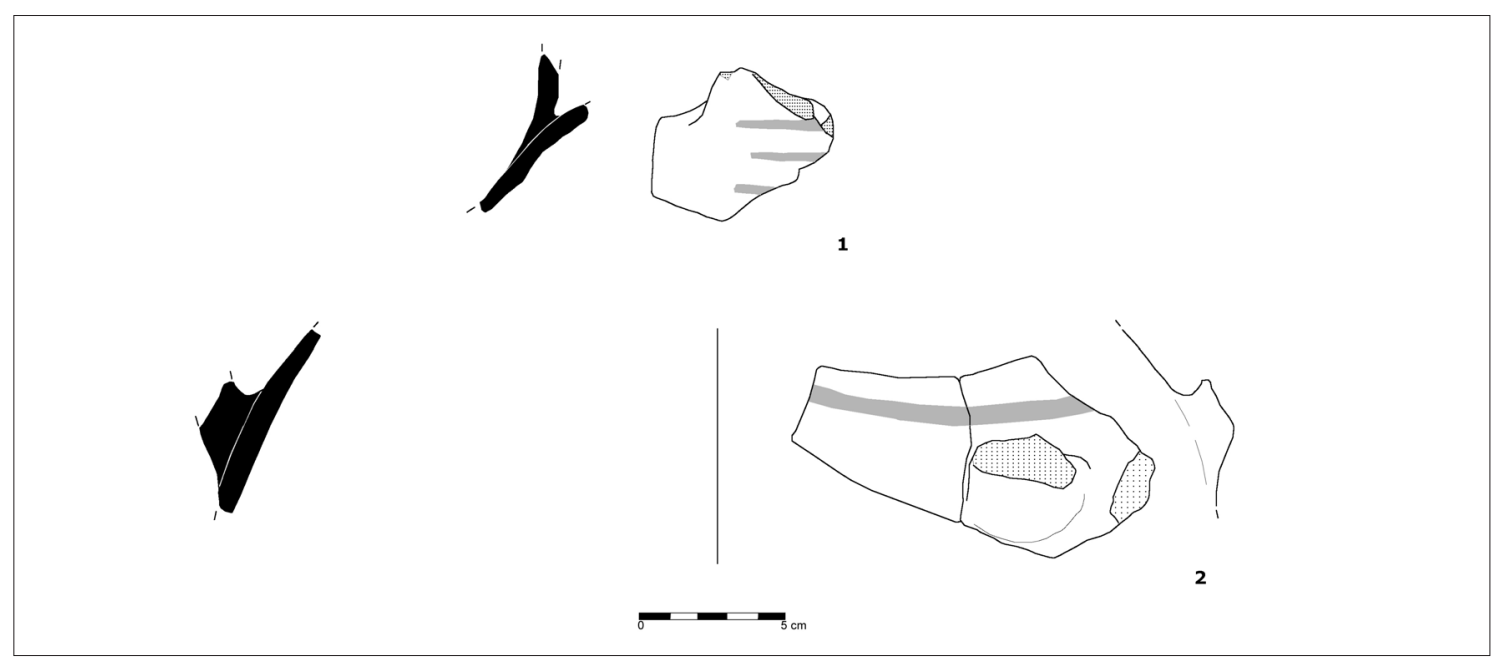

Figura 23. Contenedores pintados. 


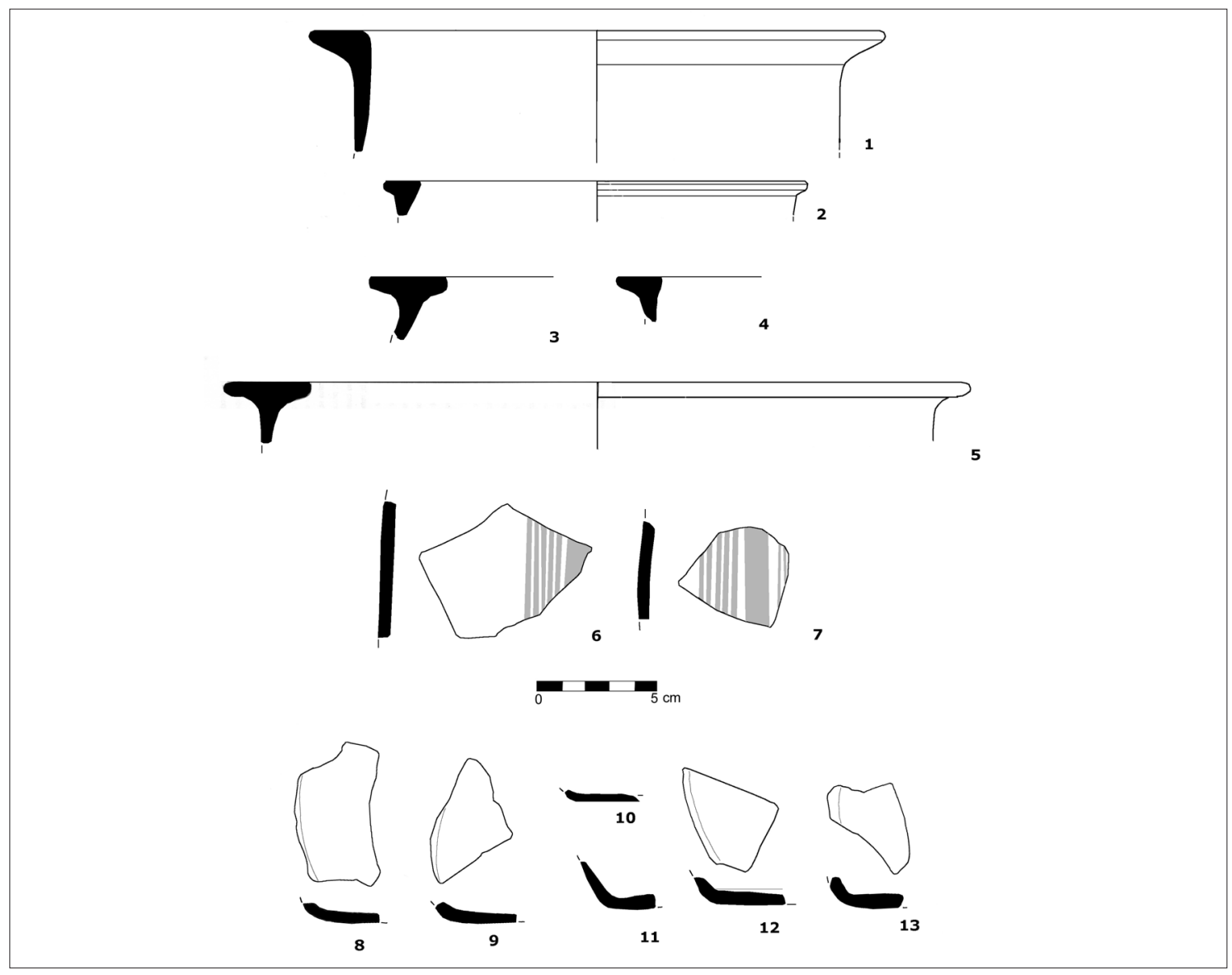

Figura 24. Kalathoi ibéricos.

dencial, en un estrato preaugusteo (UE 41), junto a un borde aristado a torno de origen mediterráneo.

\section{Contenedores pintados}

Dos de los fragmentos de cerámica a torno pintada se corresponden con recipientes de transporte o almacenaje (fig. 23). La pintura en ambos casos es de color vinoso y la pasta de la cerámica de color anaranjado. Uno de los fragmentos $\left(n^{\circ} 1\right)$ recuerda de cerca a un fragmento con asa convexo-cóncava de Cerro Macareno. La cronología de este tipo de asas pintadas que propone Pellicer $(1978,395)$ va de mediados del siglo VI a.C. al cambio de era. El fragmento $\mathrm{n}^{\circ} 2$ aparece asociado (UE 148) a una pared de kalathos, un fragmento de askós y un par de fragmentos de un vaso plástico o askoide, con lo que se podría considerar una datación de la primera mitad del siglo II a.C. Se tratarían pues de elementos de transición entre el comercio púnico y tardopúnico o tardorrepublicano.

\section{$\underline{\text { Kalathoi ibéricos }}$}

Son fácilmente reconocibles en el yacimiento por su borde plano y paredes rectas (fig. 24). Han aparecido fragmentos pertenecientes a cinco o seis recipientes distintos. Se han detectado dos tipos de pasta: una oxidante homogénea, dura, de sonido metálico y color naranja, y otra de cocción oxidante homogénea o mixta (con el alma ligeramente más oscura que la superficie), color amarillo nápoles y pasta más friable. Todos los bordes menos uno (fig. 24, no 2) pertenecen al primer tipo. Además de cinco bordes se han identificado seis fragmentos de fondo (fig. 24, 8-13), todos ellos de pasta amarillo nápoles y procedentes de la zona de habitación. Uno de ellos (fig. $24 \mathrm{n}^{\circ}$ 10) proviene de la estancia absidal adosada a la cabaña $D$.

Por lo que se refiere a las variantes morfológicas, tenemos un ejemplar (fig. 24, $\mathrm{n}^{\circ}$ 1) que encaja en el tipo A-2 de Conde (1991, 1992), con cronología de 175 a 125 a.C. El fragmento $n^{\circ} 4$ podría ser también de tipo A2 , mientras que el $\mathrm{n}^{\circ} 2$, de reducidas dimensiones y labio 


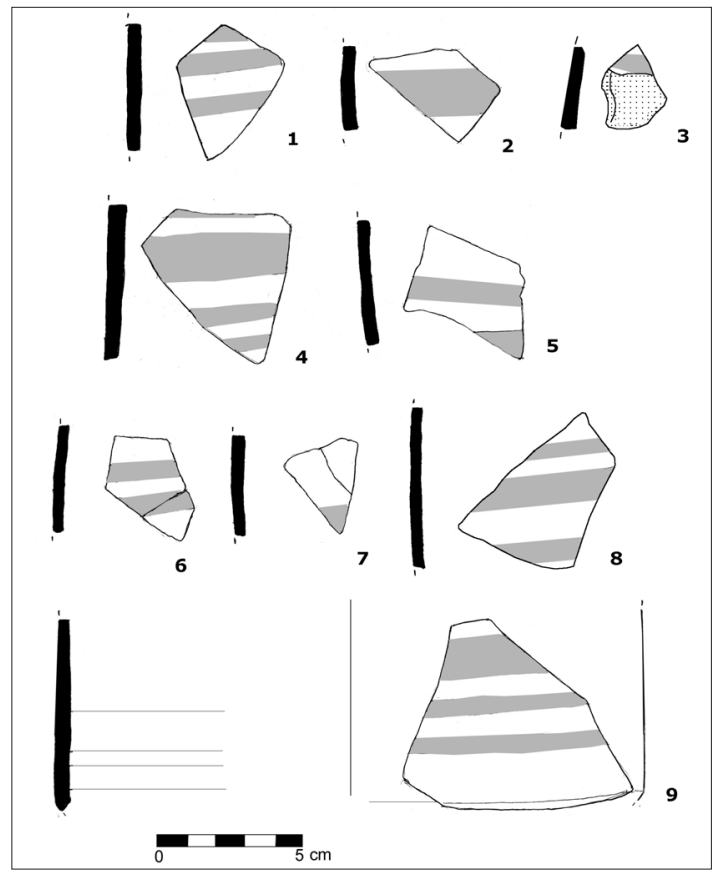

Figura 25. Paredes pintadas de kalathoi ibéricos.

poco desarrollado, presenta un aspecto bastante atípico. La cronología de los kalathoi A-1 y A-2 a mediados de la segunda centuria a.C. viene reforzada por su aparición en Segeda, en el nivel destruido en 153 a.C. (Cano et al. 2001-02). Al tipo B-6 (Conde 1992) pertenecen dos fragmentos de borde, uno procedente del conchero (fig. $24, \mathrm{n}^{\circ} 5$ ) y otro de un estrato superficial del sector de habitación (fig. 24, no 3). Su cronología se sitúa entre el 150 y el 80 a.C. Este tipo de kalathos se caracteriza por sus grandes dimensiones y por el resalte posterior del borde. Buenos paralelos fuera del noreste ibérico aparecen en el nivel púnico-romano del teatro de Malaka (Grand-Aymerich 1991, fig. 72, 1-5).

Ninguno de los bordes ha conservado decoración. Sin embargo, tenemos tres fragmentos de pared de color naranja (fig. 10, n's 6 y 7) que sí han preservado bien la pintura rojo vinoso, de tipo geométrico y con el esquema característico de los kalathoi del tipo A1 y A2 (Nicolás y Conde 1993, 21). Existe igualmente un pequeño fragmento muy rodado que conserva restos de espirales o roleos de color blanco y otros dos trozos con restos muy desvaídos del mismo color. Poseemos además un número considerable de fragmentos de pasta friable color amarillo nápoles, que conservan restos borrosos de pintura roja geométrica (fig. 25), aparentemente más anaranjada que los fragmentos mencionados, por lo que no se podría descartar la presencia de A-3 (Nicolas y Conde 1993, 24). La mala conservación de la pintura, en cualquier caso, impide pronunciarse. El fragmento de pared pintada mejor conservado (fig. $25, \mathrm{n}^{\circ}$ 9) se corresponde con la parte inferior y la carena del fondo de un kalathos. Este quiebro del perfil es especialmente característico del tipo A-2 (cf. Conde 1991, fig. 6, 1-4, fig. 9, 7). Los kalathoi tipo A-1 a 3 se fabricaron en el entorno de Ampurias, mientras que los de tipo B se corresponden con producciones de Fontescaldes (Tarragona).

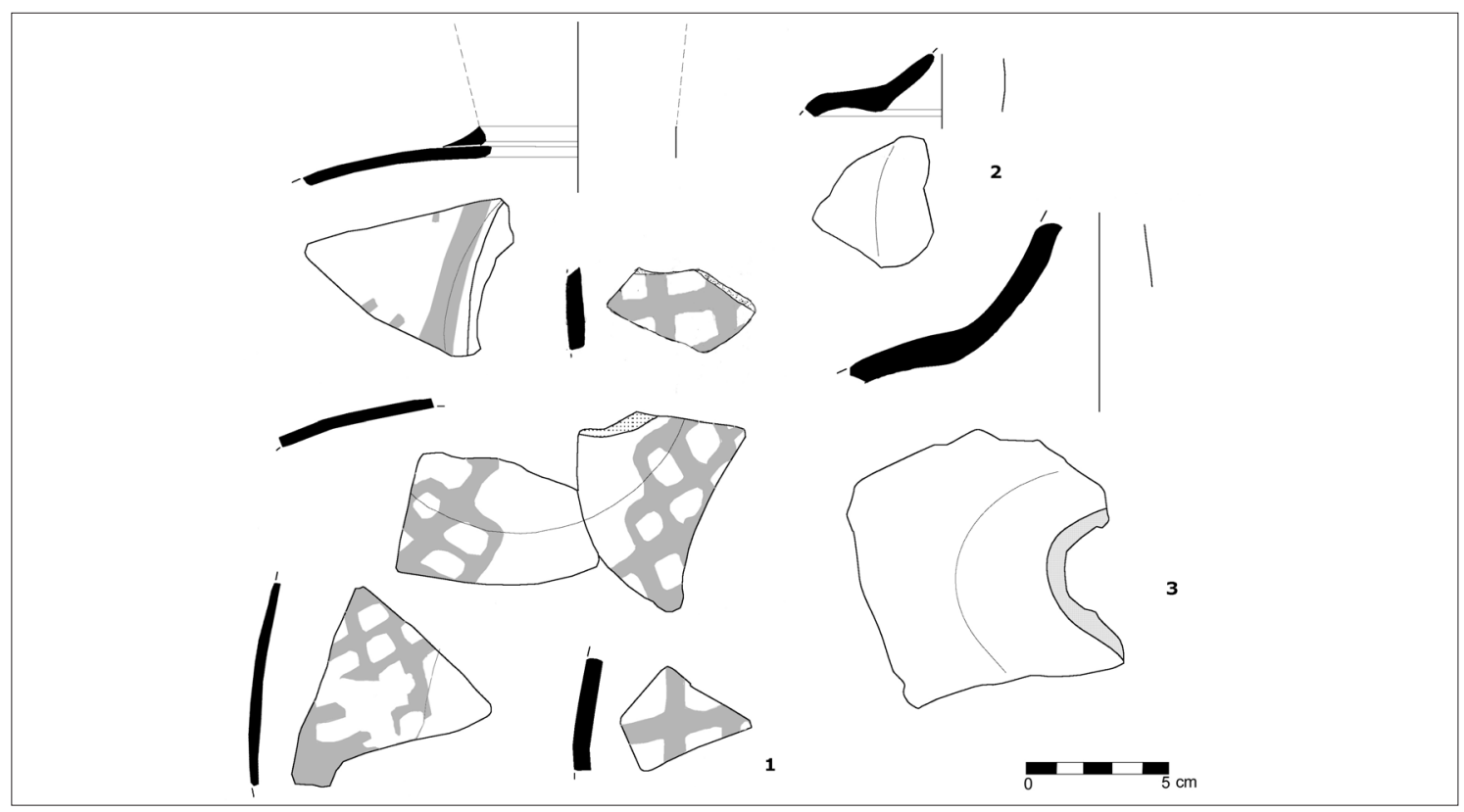

Figura 26. Askoi. 
Kalathoi ibéricos han aparecido en diversos castros del Noroeste (Conde 2001; González-Ruibal 2004, 304): Santa Trega (Peña 2001, 118), Vigo (Hidalgo 1985, XVII, 5; 1995, lám. VI, nºs 13 y 18), A Lanzada y Castrolandín, en Pontevedra; Campa Torres, en Asturias (Maya y Cuesta 2001, 157-158) y Neixón en A Coruña. Se trata predominantemente de importantes emporios comerciales-Castrolandín, en el interior de Pontevedra, sería una excepción-los cuales, en determinados casos (Santa Trega, Vigo o Campa Torres), se erigieron en centros políticos de su territorio. Probablemente su relativa frecuencia a lo largo del Mediterráneo occidental e incluso en el Cantábrico (Mezquíriz 1970; Conde 2001) se deba a que estos recipientes se utilizaban para transportar algún tipo de producto: miel, frutos secos, salazón (Nicolás y Conde 1993, 21). En general, constituye la cerámica ibérica más abundante fuera del noreste peninsular: así, en las Islas Baleares suponen el $84 \%$ de todas las cerámicas ibéricas de importación (Nicolás y Conde 1993, 20). La ruta de estos vasos hacia el Atlántico está marcada por sitios como Huelva (Rufete 2002, 171, 175), Lixus (Izquierdo et al. 2001, fig. 1, 1-3) y Conímbriga (Alarcão 1976, 8, pl. II, 47, 48, 49).

\section{Askoi y vasos plásticos}

Se han recuperado dos askoi, uno roto en varios fragmentos (fig. 26, $\mathrm{n}^{\circ}$ 1). Uno de ellos (del que ofrecemos dibujo) presenta una pasta de color amarillo-blanquecino, textura friable y decoración pintada, mientras que el segundo ejemplar (no reproducido) tiene pasta dura, de sonido metálico y color naranja homogéneo. Ambos muestran claramente huellas de torno concéntricas al interior. Aunque los askoi son especialmente abundantes en Ibiza, donde se han encontrado hornos que los fabrican, aparecen en muchos otros lugares. Su cronología se sitúa fundamentalmente entre el último cuarto del siglo III a.C. y mediados del siglo II a.C. Sería pues un elemento de transición entre el comercio propiamente púnico y el que aquí denominamos tardorrepublicano. El esquema decorativo de los fragmentos de Montealegre, a base de una retícula, es bastante peculiar, aunque no está del todo lejos de las cruces que aparecen en algún ejemplar de Turó de ses Beies (Camps y Vallespir 1974, fig. 3,105$)$. Un askós, en este caso claramente baleárico, apareció en el castro de A Lanzada (González-Ruibal 2004a). El askós decorado de Montealegre procede de la zona residencial, pero no se encuentra vinculado a estructuras de habitación: apareció en la UE 58 junto a un fondo y un fragmento de cerámica a torno amarilloblanquecina, ambos importados. El otro askós fue exhumado en el vertedero de conchas.

Además han aparecido dos fragmentos pertenecientes a vasos plásticos o askoides. El fragmento de mayor tamaño proviene del conchero (fig. $26, \mathrm{n}^{\circ} 3$ ), el menor (fig. 26, nº 2) del área de habitación. Las características de la pasta (amarilla, friable, sin desgrasante) son semejantes a las del resto de las producciones de importación procedentes del mediodía peninsular. Askoi y vasos plásticos son producciones típicas de los alfares gaditanos durante el siglo III y II a.C.

\section{LAS IMPORTACIONES DEL PERÍODO JULIO- CLAUDIO (25 A.C. -50 D.C.)}

El período comprendido entre Augusto y Claudio está muy bien representado en los castros del Noroeste a través de numerosas importaciones, especialmente las ubicuas ánforas Haltern 70 y las sigillatas itálicas y gálicas. La relevancia del horizonte comercial comprendido entre el inicio de las Guerras Cántabras y mediados de la primera centuria de la Era ha condicionado en gran medida nuestra visión de los castros de la Edad del Hierro, una visión que por fortuna comienza a cambiar con la aportación de nuevos datos. Los materiales altoimperiales de Montealegre señalan el mantenimiento de unas intensas relaciones comerciales iniciadas antes de la ocupación efectiva de Gallaecia por Roma. Sin embargo, todo parece indicar que se trata de un período breve, que llega a su fin a inicios del siglo I d.C., de forma prematura en comparación con otros castros vecinos. Si bien es verdad que el volumen de importaciones es muy notable, también ha de señalarse un empobrecimiento en la variedad de materiales: si descontamos media docena de fragmentos minúsculos de sigillata itálica (todos inferiores a dos centímetros), varios fragmentos diminutos e inclasificables de vidrio y una docena de fragmentos de cerámica común romana igualmente inclasificable, la mayor parte de las importaciones son ánforas.

\section{$\underline{\text { Ánforas }}$}

\section{-Pascual 1}

Ésta ánfora es muy probablemente una reinterpretación de los contenedores Dressel 1. Se caracteriza por presentar un perfil con tendencia ovoide y borde alargado, que en la mayoría de los casos aparece diferenciado del cuello por una incisión. Las asas son rectas y de sección ovalada y el pivote cónico. Los centros productores de este tipo son, mayoritariamente, de la zona layetana en el noreste ibérico (Pascual 1977), aunque existen producciones residuales en el sur de la Galia y en la Bética. Parece que es un tipo de amplia difusión, aunque a Gallaecia llegue de forma anecdótica, si lo comparamos con la Haltern 70 o la Dressel 1. El contenido de este tipo anfórico fue vino tarraconense con total seguridad. Cronológicamente, hace su aparición en época republicana y tiene su momento de máxima difusión bajo el Principado de Augusto. 


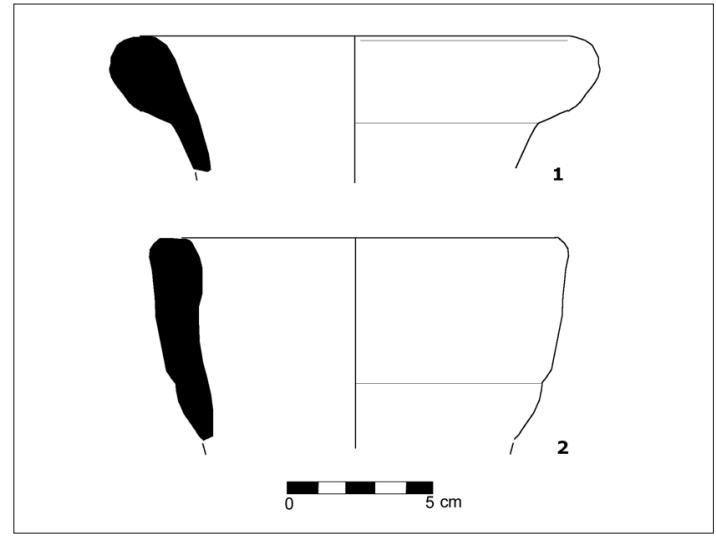

Figura 27. Ánforas Dressel 2-4 y Pascual 1.

El único fragmento recuperado en los trabajos ejecutados en Montealegre (fig. 27, $\mathrm{n}^{\circ}$ 2) pertenece un borde bien conservado procedente de niveles superficiales de la zona de habitación. La diferencia cuello-borde viene marcada por una ligera incisión, pues el fragmento que nos ocupa es apenas exvasado. La pasta presenta tonalidad rojiza en la superficie y alma naranja-amarillenta; posee una apariencia arenosa y escasa compactación, lo que nos indica una cocción defectuosa. Con seguridad, se trata de una producción tarraconense pues existen notables diferencias entre la pasta de este ejemplar de Pascual I y las pastas de los alfares del Guadalquivir, mucho más compactas y menos arenosas.

\section{-Dressel 2/4}

Se trata de uno de los tipos anfóricos más difundidos e imitados del mundo romano. Surge en Italia como envase sustituto de las itálicas Dressel 1. Morfológicamente se caracteriza por presentar un cuerpo fusiforme o tubular en el que una visible carena marca la transición cuerpo-cuello, este con forma de cono invertido. El borde puede presentar diferentes secciones (circular, ovalada, o con tendencia triangular). Este tipo de contenedores presenta un pivote muy pronunciado y macizo y, unas asas paralelas al cuello con sección bífida. El contenido de estas ánforas era vino y, sus centros de fabricación diversos, desde los prototipos originarios de

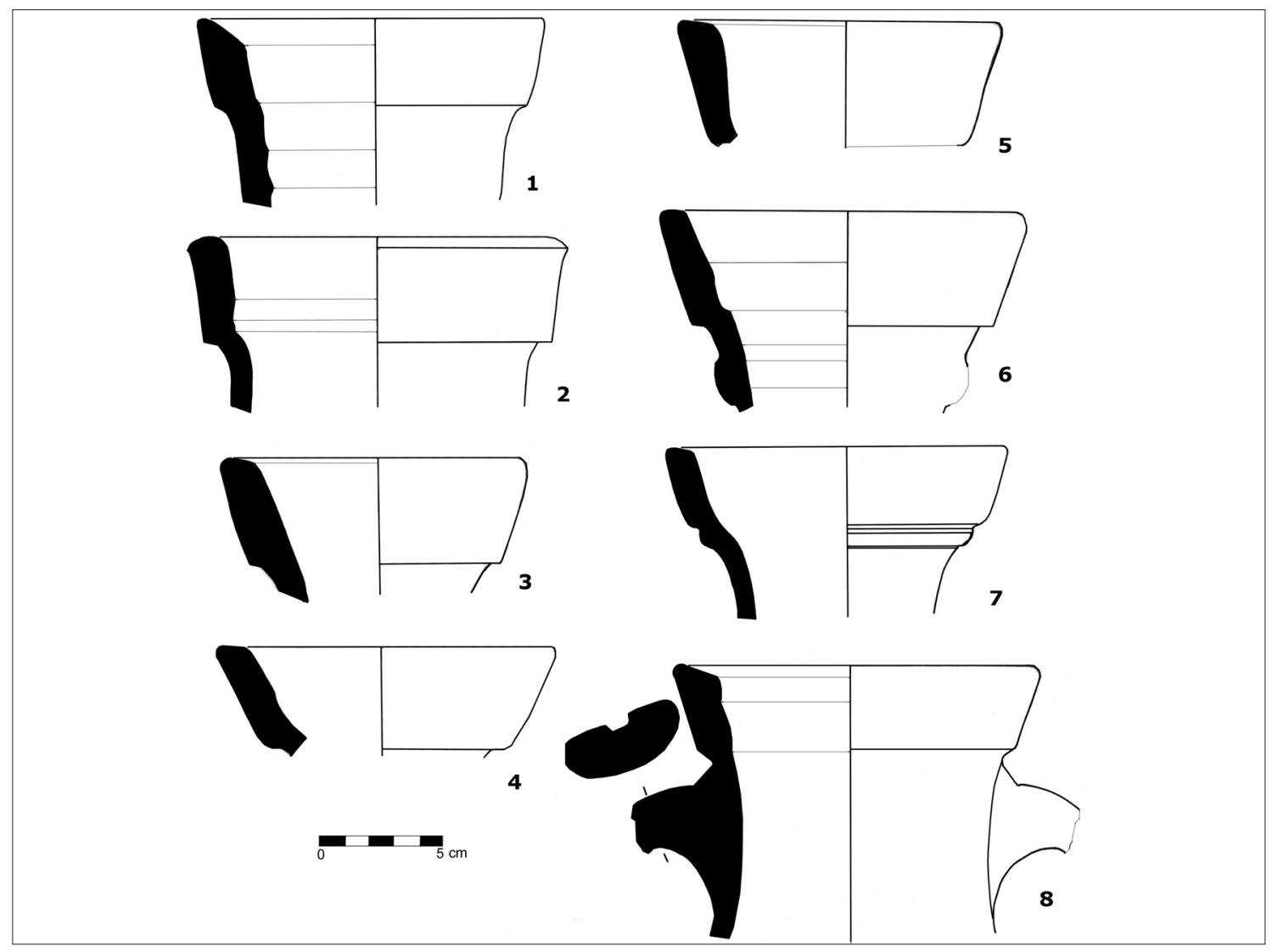

Figura 28. Ánforas Haltern 70. 


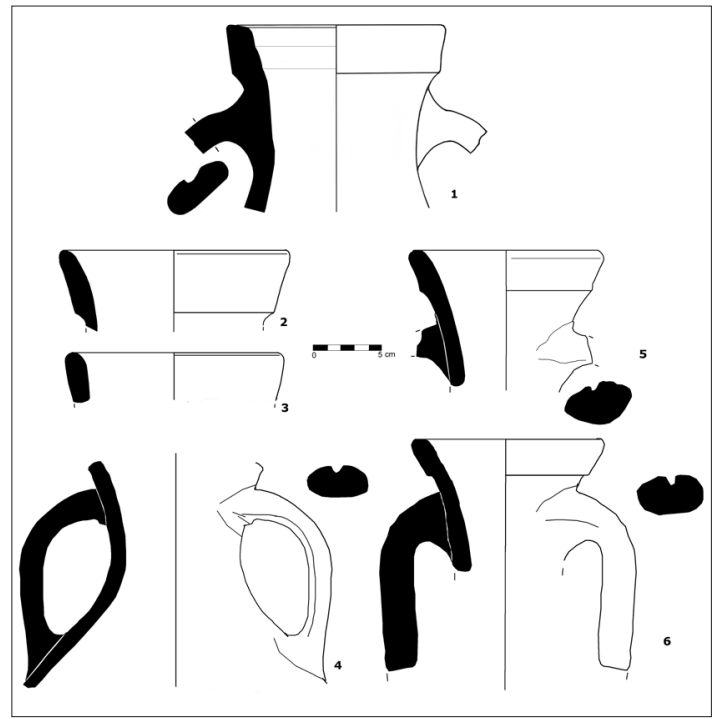

Figura 29. Ánforas Haltern 70.

Quíos, a los modelos itálicos, gálicos, tarraconenses o béticos. Cronológicamente, estamos ante un tipo coincidente en el tiempo con el descrito líneas arriba, mediados del siglo I a.C. a mediados del siglo I d.C.

El ejemplar documentado en Montealegre (Fig. 27, $n^{\circ} 1$ ) es un fragmento de borde, de sección ovalada con una pasta cremosa, áspera, amarillo-ocre. Presenta paralelos morfológicos y ceramológicos con ejemplares de Dressel 2-4 tarraconenses como los expuestos en el Museu Nacional Arqueològic de Tarragona (MNAT 34009) ${ }^{4}$ y el localizado en la campaña de excavaciones del año 2003 en el Castro de Neixón, A Coruña (Rodríguez Martínez 2005).

Este tipo de ánforas aparece conjuntamente con la Pascual I, descrita líneas arriba, en yacimientos portugueses de la fachada atlántica como Seilium o Tróia (Diogo y Cavaleiro 2001: 118; Banha y Arsénio 1998) en contextos que ofrecen un amplio abanico cronológico (30 a.C. - 150 d.C.), además se han documentado Dressel 2-4 asociadas a contenedores béticos de salazones como la Dressel 7-11 en la villa de Les Pérgoles (Pérez Suñé y Revilla 2000: 594).

\section{-Haltern 70}

A este tipo pertenecen una veintena de bordes y una decena de pivotes, así como un nutrido número de asas y fragmentos de cuello y panza (figs. 28, 29 y 30). Tres pivotes presentan grafitos precocción (fig. $30, n^{\circ}$ s 2-4). La Haltern 70 es el contenedor anfórico más difundido en

4 “Les produccions ceràmiques” http://www.mnat.es.

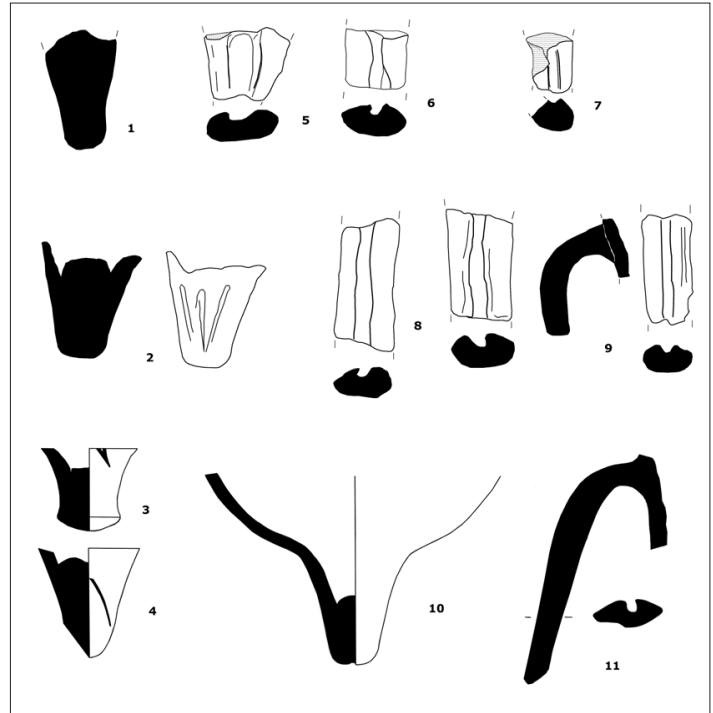

Figura 30. Ánforas Haltern 70. Pivotes y ánforas.

el NW Peninsular durante el cambio de era (Naveiro 1991). También se clasifica tipológicamente como Camulodunum 185 A, Vindonissa 583, Callender 9, Peacock \& Williams class 15, Lomba do Canho 15 A y B y Verulamium 1908 (Márquez Villora 1999: 25). Desde un punto de vista cronológico, este tipo aparece a mediados del siglo I a.C., entorno al 60-50 a.C., y desaparece en época flavia, durante el reinado de Vespasiano, entorno al 69-79 d.C (Carreras 2003). Su mayor momento de difusión se corresponde con el reinado de Augusto. Se trata de ánforas de cuerpo ovoide que llegan a alcanzar los 65$70 \mathrm{~cm}$ de altura. Como caracterización general podemos decir que presentan un borde corto y vertical, levemente convexo y vuelto ligeramente hacia fuera y marcado en su arranque por una carena más o menos pronunciada. El borde remata en un cuello corto, de unos $10 \mathrm{~cm}$. Las asas que presentan este tipo de ánforas son cortas y de sección ovalada, cortada por una acanaladura que recorre todo el largo de éstas. Arrancan próximas al borde y se desarrollan en forma curva continua. El pivote es macizo de unos $5 \mathrm{~cm}$ aproximadamente.

Este tipo de contenedores evolucionan escasamente, aunque se documentan pequeños cambios en borde, cuello y labio. A partir de tales modificaciones se establecen tres variantes (Antoni Puig, 2004, 23-32): Augustal, Claudia y Flavia, atendiendo al escalón del borde y a las formas de cuello y labio. De esta triple clasificación, en Montealegre tendríamos documentada una única variante, la augustal, que se caracteriza por un cuerpo ovoide, cuello corto y boca exvasada muy marcada en el exterior por un gran escalón sobre el arranque de las asas. Esta variante presenta equivalencias con el Grupo A de Culip VIII (Carreras, 2004; 139-147), lo que nos aportaría una 
cronología algo más precisa, estaríamos ante materiales adscribibles al período comprendido entre el 30 a.C. y el 20 d.C.

A pesar de esto, el conjunto de Haltern 70 documentado en Montealegre no es homogéneo, puesto que las pastas pueden dividirse en dos tipos a partir exclusivamente de su coloración. Así se documentan piezas caracterizadas por una tonalidad rosa-ceniza, que presentan un aspecto compacto y desgrasante (cuarzo y feldespato) de calibre medio no muy abundante y, otras caracterizadas por una tonalidad siena tostada, con abundante desgrasante, lo que le confiere un aspecto arenoso, a pesar de presentar una compactación media. Exteriormente, casi todos los fragmentos poseen restos de engobe espeso de tonalidad blanco-ceniza. Pero además de las diferencias de pastas, existe una diferencia morfológica entre los ejemplares, lo que permite establecer dos grupos o subgrupos. El primero, se caracterizaría por un borde a modo de cinta con un escalón suavizado que marca su arranque y se corona por un labio plano (fig. 28, n's 3-6). El segundo grupo se caracteriza por presentar unos bordes menos exvasados y pronunciados con un escalón resaltado a modo de arista. Además poseen un labio ligeramente apuntado e, interiormente, abundantes estrías de torno (fig. $28, \mathrm{n}^{\circ} \mathrm{s} 1$ y 8 ; fig. 29, n 1). Existe, por último, un tercer grupo más raro y quizá más antiguo (recuerda al tipo LC67) viene representado por una boca delimitada mediante una moldura de sección curva (fig. $28, n^{\circ} 7$ ). Se trata de un modelo bien documentado en Santa Trega (Peña Santos 1985-86). A un cuarto grupo, de época preagustea, hemos hecho ya mención al referirnos al horizonte anfórico cesariano.

El contenido de estos envases es muy discutido actualmente, lo que ha llevado a hablar de polifuncionalidad: podrían portar todo tipo de productos béticos: vino, derivados de éste (sapa, defructum) y/o olivas. En conclusión, a pesar de las diferencias establecidas, estamos ante materiales béticos procedentes de la desembocadura o del curso medio del Guadalquivir tal y como dejan de manifiesto las pastas y sus desgrasantes.

\section{- Dressel 7/11}

Las Dressel 7/11 son conocidas como Beltrán I, Peacock-Williams 16-17, Camulodunum 186 A y Schöne-Mau VII. Se trata de producciones béticas. Morfológicamente, presentan un cuerpo ovoide o piriforme, con un borde exvasado caracterizado por una moldura exterior. Las asas son de sección elíptica y perfil recto, con una acanaladura longitudinal similar a la que presentan las asas de la Haltern 70. Por lo que se refiere al pivote, éste suele ser largo y hueco. Fue producida en alfares de la costa bética y, en concreto, la zona del Estrecho de Gibraltar y el Bajo Guadalquivir constituyen los

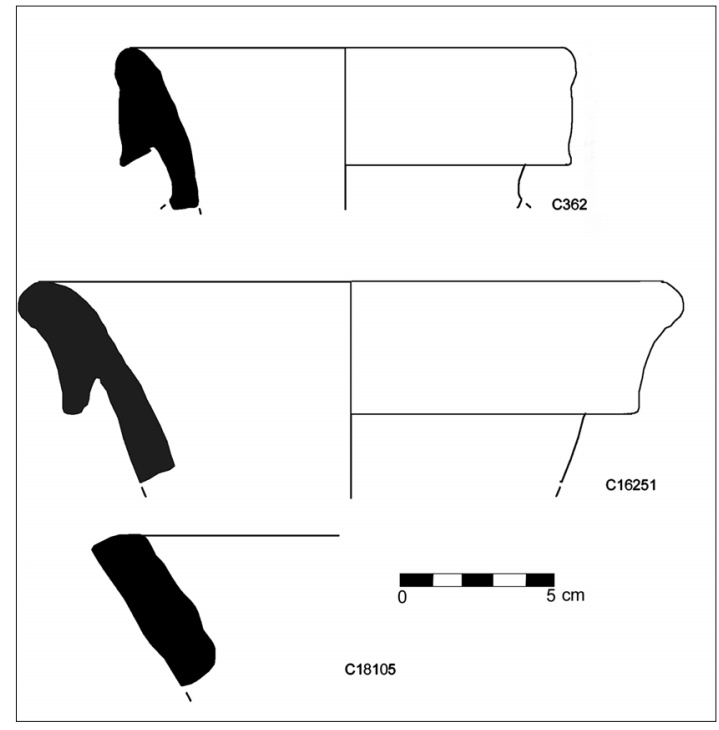

Figura 31. Ánforas Dressel 7-11.

focos más notables, aunque se realizaron imitaciones de este contenedor en alfares lusitanos, nortarraconenses o ebusitanos. Fue un contenedor empleado para el transporte de salazones, salsas y pescado, aunque se sabe que algunos ejemplares contuvieron defrutum y vino. Cronológicamente, su producción abarca un amplio abanico temporal, desde el siglo I a.C. (parece que desde el 25 a.C.) hasta inicios del siglo II d.C. Los ejemplares de Montealegre se corresponden con las tipologías más antiguas de este contenedor (cf. GranAymerich 1991: fig. 81).

Los fragmentos recuperados en el castro pertenecen mayoritariamente a bordes (fig. 31) y un asa (C16.247) de perfil recto, sección elíptica y una acanaladura que la recorre longitudinalmente. Las piezas se caracterizan por presentar una pasta beige-verdosa, de compactación media-alta, con escaso desgrasante cuarcítico. Son pastas similares a las Haltern 70 procedentes de la desembocadura y curso medio del Guadalquivir, lo cuál no resulta extraño pues se documentan alfares en los que se producen por igual ambos contenedores, caso de los alfares localizados en el entorno del Lacus Ligustinus (Carreras 2000). Pero no sólo en los centros de producción se ha documentado el binomio Dressel 7-11/Haltern 70 , en diferentes yacimientos de la fachada atlántica peninsular han aparecido en los mismos contextos. Se pueden citar como ejemplos los yacimientos de Tróia (Diogo y Cavaleiro 2001), Lisboa, Santa Trega, Castro de Vigo, A Lanzada, Neixón (González-Ruibal 2005) y Torres del Oeste (Naveiro 1995), todos ellos, puntos importantes dentro de la red de comercio establecida entre la zona del Estrecho de Gibraltar y el noroeste hispánico desde el siglo $\mathrm{V}$ a.C. 


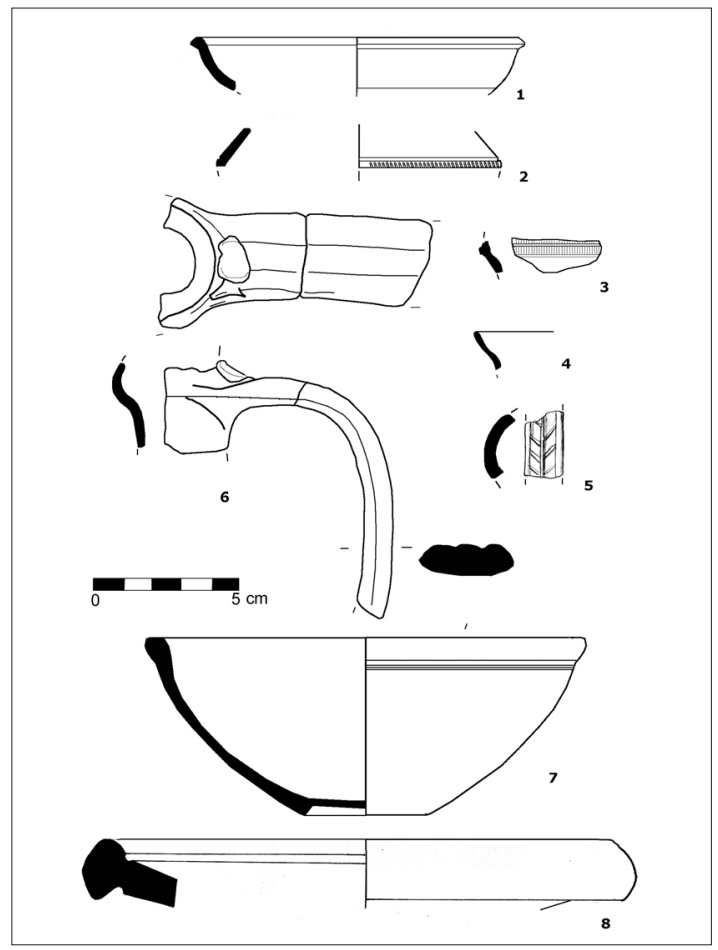

Figura 32. Cerámica común romana $(6,7)$, sigillata itálica (1-3), cerámica de paredes finas $(4,5)$ y mortero $(8)$.

\section{Cerámica común y otros}

Al período posterior a 25 a.C. pertenecen tres piezas identificables: un asa de jarra con botón, de factura grosera, con pasta arenosa de color marrón grisáceo y abundante desgrasante (fig. $32, \mathrm{n}^{\circ}$ 6); un mortero de origen bético (fig. $32, n^{\circ} 8$ ) y un cuenco de color anaranjado, pasta decantada y superficies pulidas (fig. $32, \mathrm{n}^{\circ} 7$ ). Todos ellos provienen de niveles superficiales del sector de habitación y con toda probabilidad pertenecen al último momento de uso del poblado.

En cuanto al material fino, su presencia, como señalamos más arriba, es muy escasa. Se han reconocido varios fragmentos muy rodados de sigillata itálica, de los cuales sólo tres ofrecen forma (fig. 32, $\mathrm{n}^{\mathrm{o}} \mathrm{s}$ 1-3). Los fragmentos $n^{\circ} 2$ y 3 pertenecen seguramente a la forma Goudineau 27, la más atestiguada en el Noroeste. En el pecio de Cortegada aparece junto a un cargamento de Haltern 70 (Naveiro 1984). Este conjunto se ha datado en la primera década del siglo I d.C. Además han aparecido dos pequeños fragmentos de cerámica de paredes finas (fig. 32, nº 4-5).

Por último, hay que mencionar dos monedas de Augusto procedentes del conchero (Vila Franco 2006). Una de ellas es un as de la ceca de Ébora (pri- mera emisión, 13-12 a.C.) y la otra un denario de Lugdunum (15-13 a.C.). Acuñaciones de la ceca de Ébora han aparecido también en el vecino castro de Vigo (Pereira e Hidalgo 1999). Ambos numismas acotan la ocupación julio-claudia fundamentalmente en época augustea.

\section{PERIODIZACIÓN Y PAUTAS DE COMERCIO}

Podemos distinguir tres períodos de comercio en el castro de Montealegre a partir de los materiales mediterráneos: 1) s. V - inicios del s. II a.C. 2) 150 - 25 a.C. 3) 25 a.C. -25 d.C.

1) A tenor de los datos que poseemos en estos momentos, el comercio mediterráneo en Montealegre no debió revestir gran importancia antes del final de la Segunda Guerra Púnica. Sin embargo, la comunidad de Montealegre formaba parte del círculo de intercambios de la Ría de Vigo, como ponen de manifiesto las dos ánforas T-11.2.1.4 y la cuenta de pasta vítrea recuperadas en el yacimiento. Se viene así a unir este yacimiento al de Punta do Muiño-Museo do Mar, Castro Castriño de Coia, O Areal y Toralla, todos en los alrededores de Vigo, donde las ánforas Mañá-Pascual A4 habían sido ya documentadas. Punta do Muiño y Toralla actuaron seguramente como emporia redistribuidores de los materiales mediterráneos hasta el siglo II a.C. (González-Ruibal 2006). Un motivo que podría explicar el progresivo auge de Montealegre durante el siglo II a.C. podría ser la decadencia de estos dos importantes emporios costeros de la Ría de Vigo. El primero se abandona no más tarde de mediados del siglo II a.C. (al menos el recinto fortificado), como prueba la ausencia de formas indígenas características de la Fase III castreña (150/100 a.C. - 50 d.C.), así como de ánforas itálicas o tardopúnicas. Punta do Muiño también se debió abandonar durante el siglo II a.C., aunque aquí sí se han localizado ánforas Mañá C2b en los estratos superiores. El castro debió seguir desempeñando una labor de fondeadero tardíamente-ya que no de lugar de habitación-seguramente al servicio del castro de Vigo. Al período comprendido entre fines del siglo III a.C. y mediados del siglo II a.C. podrían atribuirse algunos materiales, como los askoi y los primeros kalathoi.

2) A partir de mediados del siglo II a.C. comienza el principal episodio de comercio preaugusteo en el yacimiento, que es el último momento en que el comercio con el Atlántico se encuentra monopolizado por las comunidades púnicas del Estrecho. Podemos distinguir aquí dos contextos cronológicos:

2a) 150 a.C. -50 a.C.

2b) 50 a.C. -25 a.C. 


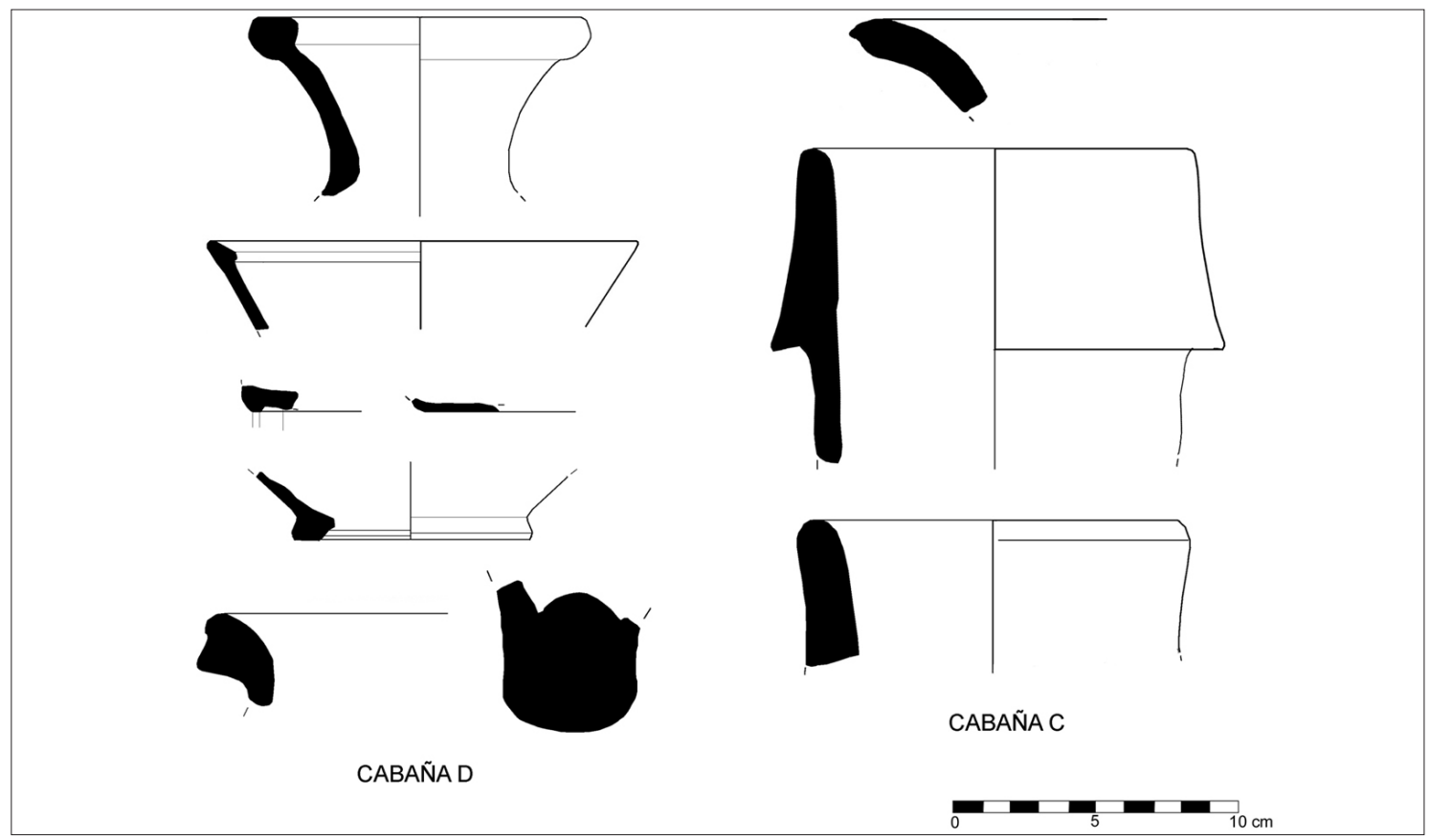

Figura 33. Materiales de importación asociados a las cabañas C (Dressel 1 y Mañá C2b) y D (cerámica común tardorrepublicana, kalathos, Dressel 1, Lusitana 1).

La datación del episodio 2 a viene dada por la aparición en los suelos de la cabaña $\mathrm{C}$ y $\mathrm{D}$, de fragmentos de ánfora Mañá C2b y Dressel 1 de fabricación itálica (fig. 33). A este momento pertenecen también los kalathoi del noreste peninsular. La tríada Dressel 1-Mañá C2b-kalathos caracteriza un horizonte de comercio presente en un número ya notable de castros del Noroeste, entre los que destacan Santa Trega, Vigo y A Lanzada. Se trata siempre de importantes puertos de comercio, en ocasiones con categoría de oppidum (Santa Tegra y Vigo). Significativamente, el período comprendido entre mediados del siglo II e inicios del siglo I a.C. coincide con el desarrollo de los grandes oppida del Noroeste (González-Ruibal 2005a), en paralelo al de otras zonas de la Europa templada. No sería descabellado pensar que la aparición de grandes poblados, con unas elites capaces de atraer productos foráneos en cantidad y especialmente aquellas involucrados en la economía política de los banquetes, contribuyera a fomentar las relaciones comerciales con el Mediterráneo. Tal fenómeno se atestigua en la mayor parte de la Europa templada, donde los grandes oppida reciben ingentes cantidades de ánforas vinarias itálicas (p.ej. Laubenheimer 1991).

Resulta interesante comprobar que el paquete de importaciones mencionado se encuentra en otros lugares de la Península Ibérica y el norte de África: desde Conímbriga (Alarcão et al. 1976) hasta Cartago
(Izquierdo et al. 2001; Kouici 2002), lo que indica que Gallaecia, al menos por lo que se refiere a su área costera, se hallaba inmersa en la misma red de comercio que ponía en conexión todo el Mediterráneo occidental. La cerámica campaniense debe incluirse en el mismo grupo de importaciones; sin embargo, su presencia resulta por ahora muy limitada en el Noroeste, especialmente más allá del área ocupada por oppida. Así, en Galicia sólo el oppidum de Santa Trega ha proporcionado una cantidad destacable (Peña Santos 2001). Esto puede deberse al rechazo local de este tipo de productos por criterios que tienen que ver con la capacidad de acción social (González-Ruibal 2006, 143). Durante este período ha de señalarse la presencia de un interesante desembarcadero en los alrededores del oppidum de Vigo, coetáneo de Montealegre, donde ha aparecido un importante lote de ánforas Mañá C2b.

Tras este episodio podríamos hablar de un episodio $2 \mathrm{~b}$ u "horizonte cesariano" (ca. 75/50-25 a.C.) caracterizado por las LC 67 y las primeras Haltern 70, así como por algunas Dressel 1 de fabricación bética. Este horizonte marcaría el inicio del control propiamente romano (o más bien de la desaparición del monopolio púnico) sobre la ruta del estaño, a partir de las expediciones de Craso y especialmente César. Este episodio comercial se encontraría particularmente bien caracterizado en el castro de Santa Trega (Peña Santos 1984-85, 1986), donde han aparecido un número muy elevado de LC 67. 
Es probable que buena parte de la campaniense B de ese yacimiento deba relacionarse con este episodio.

3) Finalmente, el horizonte Julio-Claudio (25 a.C. 50 d.C.) vendría marcado por la entrada de Haltern 70 en gran cantidad, en menor medida Dressel 7/11, y algunos otros contenedores, como Pascual 1. Durante esta época se produce la llegada de sigillata itálica, que es la primera vajilla fina de importación que se populariza realmente en el Noroeste-al menos en los poblados costeros y grandes oppida. El comienzo de este episodio vendría marcado por las Guerras Astur-Cántabras, la anexión efectiva de Gallaecia al imperio, la reorganización administrativa del territorio y la llegada masiva del comercio romano más allá del litoral, un hecho ejemplificado sobre todo por el enorme volumen de Haltern 70 . En realidad, es bastante probable que este horizonte, en el caso de Montealegre, sea únicamente augusteo, dada la ausencia de materiales claramente post-augusteos. Esto plantearía un final para el castro en torno a la segunda década del s. I d.C.

En cierto modo, las pautas de consumo a partir de Augusto serían comparables a las iniciadas a mediados del siglo II a.C.: se puede hipotetizar que, al menos en parte, las relaciones comerciales con el Mediterráneo se vieron favorecidas por el surgimiento de unas elites poderosas en el sur de Gallaecia. Dentro de la economía política de dichas elites, como en otras partes de Europa (Dietler 1990, Dietler y Hayden 2001), es verosímil que los banquetes, y el vino mediterráneo, jugaran un papel importante: de ahí las numerosas ánforas que pueblan los asentamientos de fines del Hierro. La más que notable presencia de Haltern 70 en Montealegre, como en tantos otros poblados coetáneos del Noroeste, podría quizá explicarse por la pervivencia, al menos en los primeros años de ocupación romana, de una política de banquetes de raigambre prerromana.

En fechas recientes se ha puesto en duda que las Haltern 70 contengan vino. Los tituli picti hacen referencia a defructum, sapa y mulsum, que algunos autores entienden como mosto o sazonadores del vino propiamente dicho (García Vargas 2004). También se considera que las Haltern 70 pudieran transportar conservas y aceitunas (cf. referencias en Fitzpatrick 2003; Morais 2004a). No obstante, en el Noroeste ibérico resulta más verosímil el transporte de una bebida alcohólica. El gran volumen de ánforas de esta tipología en ciudades romanas como Brácara (Morais 1998; 2004a) y en castros (Morais 2004a, 550), la existencia de un pecio que transportaba un cargamento exclusivo de Haltern 70 (Naveiro 1984) o el hecho de que la Haltern 70 constituya el $80 \%$ de todas las ánforas del Noroeste (Naveiro 1990, 66-67) hacen muy poco probable que estos contenedores transportasen un producto no alcohólico (Morais 2004a, 547), al menos como norma general. De hecho, la aparición masiva y casi excluyente de la Haltern 70 , frente a otros contenedores vinarios, puede explicarse por la demanda de un producto alcohólico específico, acorde con las necesidades locales, así como por los intereses económicos de los comerciantes béticos, que probablemente llevarían vinos fuertes y de baja calidad a los "bárbaros" del norte (Morais 2004a, 549). Esto hace pensar también que otros contenedores prerromanos, como la Mañá $\mathrm{C} 2 \mathrm{~b}$, pudieran haber transportado también vino al Noroeste. La llegada de salazones de pescado a una zona eminentemente costera y ajena a los gustos culinarios mediterráneos como Gallaecia es poco probable en un momento tan temprano: las ánforas de salazón no se generalizan en esta zona antes del siglo II d.C. Hasta entonces, su presencia es muy reducida. Cabría la posibilidad, sin embargo, de que algunas Haltern 70 y C2b sí transportaran salazones: este sería el caso si hubiese individuos del mediodía peninsular viviendo en Montealegre. A ello nos referiremos seguidamente.

\section{CONCLUSIÓN}

La historia de los contactos comerciales del castro de Montealegre desde el siglo V a.C. hasta las primeras décadas del siglo I d.C. pone en tela de juicio la extrema marginalidad del Noroeste ibérico respecto a las redes comerciales del Mediterráneo. Esta marginalidad, que es indudablemente real, aparece no obstante exagerada por la investigación, debido tanto a una escasez tradicional de buenos estudios sobre contactos comerciales preagusteos, como a la asunción de que los pueblos del norte peninsular se encontraban casi por completo ajenos al mundo mediterráneo-aunque esta asunción está siendo sometida a crítica en la actualidad (cf. Domínguez Pérez 2006). Con la publicación de los materiales de importación de yacimientos como Montealegre, habrá que empezar a repasar las distribuciones de cerámicas mediterráneas (Mañá C2b, Dressel 1, kalathoi, askoi), que suelen dejar un gran vacío en la mitad norte de la costa atlántica peninsular. Asimismo, es de suponer que nuevas intervenciones en lugares costeros permitirán consolidar, con nuevos datos, la idea de que el Noroeste se hallaba bien integrado en las redes comerciales del Estrecho de Gibraltar y, por extensión, del Mediterráneo.

Para concluir, nos gustaría avanzar la posibilidad de que en Montealegre existiese una presencia de mercaderes mediterráneos, al menos estacional, desde mediados el siglo II a.C. o inicios de la siguiente centuria. La presencia foránea en emporia galaicos ya ha sido aventurada por Súarez Otero (2004) para el yacimiento de Punta do Muíño, debido al gran lote de ánforas y cerámica común púnica allí documentada. Los materiales 
alógenos localizados en Montealegre se pueden clasificar, fundamentalmente, en dos familias: contenedores (ánforas, tinajas, kalathoi) y cerámica común (cuencos, tazas, ollas). Este tipo de materiales, unido a una marcada escasez de productos finos, se suele considerar característico de pequeños emporia, con una población foránea reducida y no permanente (López Pardo 1992, 281-83). La existencia de morteros, en particular, resulta difícil de entender sin la presencia de individuos mediterráneos acostumbrados a utilizar este tipo de productos. No es casual que en el Noroeste se haya comprobado la presencia de los morteros IIA en Brácara (Morais 2004), una ciudad de fundación romana, y en A Lanzada, un importante emporio costero. Las piezas que se pueden identificar como morteros en castros indígenas son sumamente escasas, incluso en aquellos que continúan ocupados hasta bien entrado el siglo I d.C. En cambio, es bien sabido que en los barcos mercantes mediterráneos viajaban cerámicas de cocina y mesa, incluidos morteros, que utilizaba la tripulación para preparar y consumir sus propios alimentos durante la travesía. Así, en el pecio de El Sec, del siglo IV a.C., han aparecido además de ollas, cazuelas, jarras y lebrillos, algunos fragmentos de mortero (Arribas et al. 1987, 514-517). Es muy posible, además, que algunas de las ánforas de Montealegre transportasen salazones y aceites mediterráneos para consumo de los mercaderes que vivirían estacionalmente en el castro. El hecho de que otras piezas, como los ungüentarios, sólo se hayan localizado hasta la fecha de forma excepcional y en castros costeros con importante volumen de importaciones (A Lanzada), también permitiría sospechar que su uso sería propio de los navegantes más que de las poblaciones locales.

Dejamos planteada, pues, la posibilidad de que en Montealegre, como probablemente en otros castros costeros galaicos, viviesen de forma estacional mercaderes del sur de la Península Ibérica.

\section{BIBLIOGRAFÍA}

ABOAL FERNÁNDEZ, R. y CASTRO HIERRO, V., eds., 2006, O castro de Montealegre (Moaña, Pontevedra). Noia.

ALARCÃO, J. DE, DELGADO, M., MAYET, F., MOUTINHO ALARCÃO, A. e PONTE, S. da, 1976, Fouilles de Conimbriga. VI. Céramiques diverses et verres. Paris.

ALCORTA IRASTORZA, E., 2000, Lucus Augusti, 2. Ceramica común romana de cocina y mesa hallada en las excavaciones de la ciudad. A Coruña.

ALMAGRO GORBEA, Ma . J., 1984, La necrópolis de Baria (Almería). Campañas de 1975-78. Excavaciones Arqueológicas en España 129. Madrid.
ALVES, F., DIOGO, A. M. D. y CARDOSO, J. P., 2001, Considerações sobre os dois grandes cepos de âncora em chumbo com alma de madeira, do séc. V-IV a.C., provenientes do ancarodouro natural da ilha Berlanga (Peniche) e sobre os achados de ânforas de "tipo púnico" em águas portuguesas. En A.A. Tavares (ed.): Os púnicos no extremo occidente. Actas do colóquio internacional (Lisboa 2000). Lisboa, 239260.

ARRIBAS, A., TRÍAS, Mª G., CERDÁ, P. Y HOZ, J. DE, 1987, El barco de El Sec (Costa de Calvià, Mallorca). Calvià.

AYÁN VILA, X., ed., 2005, Os castros de Neixón. A recuperación dende a arqueoloxía dun espazo social e patrimonial. Noia.

BANHA, C. M. DOS S. y ARSÉNIO, P. D. M., 1998, As ânforas romanas vinárias de Seilium (Tomar), conuentus Scallabitanus. Revista Portuguesa de Arqueologia 1(2): 165-189.

BERNAL, D., LORENZO, J., EXPÓSITO, J., SÁEZ, A. y DÍAZ, J., 2004, Las innovaciones tecnológicas itálicas en la alfarería gadirita (s. II a.C.). A propósito del taller anfórico de la Avda. de Portugal. En D.Bernal y L. Lagóstena (eds.): Figlinae Baeticae. Talleres alfareros y producciones cerámicas en la Bética romana (ss. II a.C. - VII d.C.). vol. 2. Oxford, 621632.

CALO LOURIDO, F. y SOEIRO, T., 1986, Castro de Baroña. Campañas 1980/84. Arqueoloxía / Memorias 6. Santiago de Compostela.

CALVO SÁNCHEZ, I., 2001, Monte de Santa Tecla. Memorias arqueológicas. Años 1914-1920, 1920 1923. A Guarda.

CAMPANELLA, L., 1999, Ceramica punica di età ellenistica da Monte Sirai. Collezione di Studi Fenici 39. Roma: Consiglio Nazionale delle Ricerche.

CAMPS COLL, J. y VALLESPIR BONET, A., 1974, La estación del "Turó de ses Beies" (Calvià). En Prehistoria y arqueología de las Islas Baleares. VI Simposio de Prehistoria Peninsular, Barcelona, 101114.

CANO DÍAZ-TENDERO, Mª A., LÓPEZ ROMERO, R., SAIZ CARRASCO, Ma . E., 2001-02, Kalathos aparecidos en las excavaciones arqueológicas de Segeda I, Área 3. Kalathos 20-21: 189-214.

CARDOZO, M., 1976, Citânia de Briteiros e castro de Sabroso. Guimarães.

CARRERAS MONFORT, C., 2000, Producción de Haltern 70 y Dressel 7-11 en las inmediaciones del Lacus Ligustinus (Las Marismas, Bajo Guadalquivir). En Congreso Internacional ex Baetica Amphorae (Sevilla - Écija, Diciembre 1998). Écija, 419426.

CARRERAS MONFORT, C., 2001, Ánforas de la Campa Torres (Campañas 1985 - 1997). En Maya, 
J.L. y Cuesta, F. (eds.): El castro de La Campa Torres. Gijón: 389-392.

CARRERAS MONFORT, C., 2003, Haltern 70: a review. Journal of Roman Pottery Studies 10: 85-91.

CARRERAS MONFORT, C., 2004, Tipologia d'Haltern 70 del Culip VIII. En C. Carreras et al.: Culip VIII i les àmfores Haltern 70. Monografies del Casc 5. Museu d'Arqueologia de Catalunya. Girona: Centre d'Arqueologia Subaquàtica de Catalunya, Girona, 139-147.

CINTAS, P., 1950, Céramique punique. Paris.

CONDE BERDÓS, M. J., 1991, Les produccions de kálathoi d'Empùries i la seva difusió mediterrània (segles II-I a.C.). Cypsela 9: 141-168.

CONDE BERDÓS, J. C., 1992, Una produció cerámica característica del mon ibèric tardà: el kalathos "barret de copa". Fonaments 8: 117-169.

CONDE BERDÓS, J. C., 2001, La cerámica ibérica. En J.L. Maya y F. Cuesta, eds.: El castro de Campa Torres. Período prerromano. Gijón: 385-387.

DÍAZ, M., 2000, Tipocronología de los contextos cerámicos tardo-republicanos en Tarraco. Empúries 52: 201-260.

DIETLER, M., 1990, Driven by drink: the role of drinking in the political economy of and the case of Early Iron Age France. Journal of Anthropological Archaeology 9(4): 352-406.

DIETLER, M. y HAYDEN, C., eds., 2001, Feasts: archaeological and ethnographic perspectives on food, politics, and power. Washington, D.C.

DIOGO, A. M. D., 1996, Elementos sobre ânforas de fabrico lusitano. En Ocupação Romana dos Estuários de Tejo e do Sado. Lisboa/Seixal.

DIOGO, A. M. D. y CAVALEIRO, A., 2001, Ânforas de escavações no povoado industrial romano de Tróia, Setúbal. Revista Portuguesa de Arqueologia 4(1): 117-140.

DOMÍNGUEZ PÉREZ, J. C., 2006, Gadir y los fenicios occidentales federados V-III a.C. Dialéctica aplicada al territorio productivo turdetano. BAR International Series 1513. Oxford.

DORE, J. N. y SCHINKE, R., 1992, First report on pottery. En N. Ben Lazreg u D.J. Mattingly (eds.): Leptiminus (Lamta): A Roman port city in Tunisia. Report $n^{\circ} 1$. Journal of Roman Archaeology Supplementary Series 4, 115-156.

FABIÃO, C., 1989, Sobre as ânforas do acampamento romano da Lomba do Canho (Arganil). Cadernos da Unidade de Arqueologia 1. Lisboa.

FABIÃO, C. y GUERRA, A., 1994, As ocupações antigas de Mesa do Castelinho (Almodôvar). Resultados preliminares das campanhas de 1990-92. Actas das $V$ Jornadas Arqueológicas da Associação dos Arqueólogos Portugueses (Lisboa 1993), vol. 2, Lisboa, 275-289.
FERNÁNDEZ RODRÍGUEZ, C., 2006, Os recursos de orixe animal: primeiros datos e avaliación preliminar. En R. Aboal y V. Castro (eds.): O Castro de Montealegre (Moaña, Pontevedra). Noia, 323-331.

FITZPATRICK, A. P., 2003, Roman amphorae in Iron Age Britain. En J. Plouviez (ed.): Amphorae in Britain and the Western Empire. Journal of Roman Pottery Studies 10. Oxford, 10-25.

GARCÍA VARGAS, E., 2000, La producción de ánforas "romanas" en el sur de Hispania. República y Alto Imperio. Congreso Internacional ex Baetica Amphorae (Sevilla-Écija, Diciembre 1998). Écija, 57-174.

GARCÍA VARGAS, E., 2004, Las ánforas de vino bético altoimperial: formas, contenidos y alfares a la luz de algunas novedades arqueológicas. En D.Bernal y L. Lagóstena (eds.): Figlinae Baeticae. Talleres alfareros y producciones cerámicas en la Bética romana (ss. II a.C. - VII d.C.). vol. 2. Oxford, 507-514.

GOMES, M. V., 1993, O establecimento fenicio-púnico do cerro da Rocha Branca (Silves), Os Fenicios no Território Portugues: Estudos Orientais 4, Lisboa, pp. 73-107.

GONZÁLEZ-RUIBAL, A., 2004, Facing two seas: Mediterranean and Atlantic contacts in the NW of Iberia. Oxford Journal of Archaeology 23(3): 287317.

GONZÁLEZ-RUIBAL, A., 2004a, Un askós ibicenco en Galicia: notas sobre el carácter del comercio púnico en el Noroeste de la Península Ibérica. Complutum 15: 33-43

GONZÁLEZ-RUIBAL, A., 2005, Análise do material cerámico exhumado. En X. Ayán Vila (coord.): Os Castros do Neixón, Boiro, A Coruña. A recuperación dende a arqueoloxía dun espazo social e patrimonial. Noia: Toxosoutos, 204-229.

GONZÁLEZ-RUIBAL, A., 2005a, El castro de Saceda y la jerarquización territorial en la Segunda Edad del Hierro del Noroeste ibérico. Zephyrus 58: 275-292

GONZÁLEZ-RUIBAL, A., 2006, Past the last outpost. Punic merchants in the Atlantic $\left(5^{\text {th }}-1^{\text {st }}\right.$ c. BC). Journal of Mediterranean Archaeology 19(1): 151170.

GONZÁLEZ-RUIBAL, A. y RODRÍGUEZ MARTÍNEZ, R., 2006, A cerámica indíxena e de importación. En R. Aboal y V. Castro, eds.: $O$ castro de Montealegre (Moaña, Pontevedra). Noia, 145-188.

GRAN-AYMERICH, J., 1991, Malaga phénicienne et punique. Recherches franco-espagnoles 1981-1988. Paris.

GUERRERO AYUSO, V., 1984, Asentamiento púnico de $\mathrm{Na}$ Guardis. Excavaciones Arqueológicas en España 133. Madrid: Ministerio de Cultura.

HIDALGO CUÑARRO, J. M., 1985, Castro de Vigo. Campaña de 1983. Arqueoloxía / Memorias 1. Santiago de Compostela. 
HIDALGO CUÑARRO, J. M., 1995a, Nuevas aportaciones al estudio del castro de la isla de Toralla (Vigo). XXII Congreso Nacional de Arqueología vol. 2, Vigo 1993: 195-202.

IZQUIERDO PERAILE, I., ALAOUI, M. K., BONET ROSADO, H., MILOU, I., 2001, Las fases púnicomauritanas I (175/50 a 80/50 a.C.) y II (80/50 a.C. 15 d.C.). En Aranegui Gascó, C. (ed.): Lixus. Colonia fenicia y ciudad púnico-mauritana. Anotaciones sobre su ocupación medieval. Saguntum Extra 4, Valencia.

KOUICI, N., 2002, Los contactos entre la Península Ibérica y el norte de África según los datos histórico-arqueológicos de época púnico-romana. SPAL 11: 277-296

LAGÓSTENA BARRIOS, F., 1996, Explotación del salazón en la Bahía de Cádiz en la Antigüedad: Aportación al conocimiento de su evolución a través de la producción de las ánforas Mañá C. Florentia Iliberritana 7: 141-169.

LAUBENHEIMER, F. 1991, Les amphores de Bibracte. Le materiel des fouilles anciennes. DAF, 29, Maison des Sciences de l'Homme, Paris.

LÓPEZ CASTRO, J. L., 1995, Hispania Poena. Las fenicios en la Hispania romana. Barcelona.

LÓPEZ PARDO, F., 1992, Mogador "factoría extrema" y la cuestión del comercio fenicio en la costa atlántica africana. In Actes du Ve Colloque International d'Histoire et Archeologie de l'Afrique du Nord (Avignon, 9-13 avril, 1990), 277-96. Paris.

LOSADA DIÉGUEZ, A.,1927, Excavaciones en Montealegre (Domayo) Provincia de Pontevedra. Memoria de la Junta Superior de Excavaciones y Antigüedades 90, Madrid.

MEZQUÍRIZ, M. A., 1970, Un kalathos ibérico. Hallazgo submarino en Fuenterrabía (Guipúzcoa). XI Congreso Arqueológico Nacional, Zaragoza: 515-517.

MORAIS, R., 1998, As Ânforas da Zona das Carvalheiras. Cadernos de Arqueologia, Monografias. Braga.

MORAIS, R., 2004, Os almofarizes béticos em Bracara Augusta. En D.Bernal y L. Lagóstena (eds.): Figlinae Baeticae. Talleres alfareros y producciones cerámicas en la Bética romana (ss. II a.C. - VII d.C.). vol. 2. Oxford, 567-570.

MORAIS, R., 2004a, Bracara Augusta: um pequeno "testaccio" de ânforas Haltern 70. Considerações e problemáticas de estudo. En D.Bernal y L. Lagóstena (eds.): Figlinae Baeticae. Talleres alfareros y producciones cerámicas en la Bética romana (ss. II a.C. - VII d.C.). vol. 2. Oxford, 545-566.

NAVEIRO LÓPEZ, J., 1982, As ánforas romanas de A Coruña (II). Brigantium 3: 63-74.

NAVEIRO LÓPEZ, J., 1984, Un pecio romano en Cortegada (Villagarcía de Arosa). II Coloquio Galaicominhoto, vol. 2: 273-283.
NAVEIRO LÓPEZ, J., 1991, El comercio antiguo en el N.W. Peninsular. Monografías Urxentes do Museu $\mathrm{n}^{\circ}$ 5. A Coruña.

NAVEIRO LÓPEZ, J., 1995, Escavación arqueolóxica nas Torres do Oeste (Catoira, Pontevedra). Arqueoloxía/Informes 3. Santiago de Compostela: 71-75.

NICOLÁS MASCARÓ, J. C. DE y CONDE BERDÓs, Ma . J., 1993, La cerámica ibèrica pintada a les Illes Balears i Pitiuses. Mahón.

NIVEAU DE VILLEDARY y MARIÑAS, A. Mª., 2002, Las ánforas turdetanas del tipo Pellicer-D ensayo de clasificación. Spal 11: 233-252.

NUNES, J. DE C., FABIÃO, C. y GUERRA, A. 1989, O acampamento militar romano da Lomba do Canho (Arganil): ponto da situação. Actas do I Colóquio Arqueológico de Viseu. Viseu: 403-424.

PASCUAL GUASCH, R., 1977, Las ánforas de la Layetania. En G. Vallet (ed.): Méthodes classiques et méthodes formelles dans l'étude des amphores. Roma, 47-96.

PELLICER CATALÁN, M., 1978, Ánforas prerromanas del Guadalquivir, según el Cerro Macareno (Sevilla). Habis 9: 365-401.

PEÑA SANTOS, A. DE LA, 1985-86, Tres años de excavaciones arqueológicas en el yacimiento galaico-romano de Santa Tegra (A Guarda-Pontevedra): 1983-1985. Pontevedra Arqueológica 2: 157-189.

PEÑA SANTOS, A. DE LA, 1986, Yacimiento galaicoromano de Santa Trega (A Guarda, Pontevedra). Campaña de 1983. Arqueoloxía / Memorias 5. Santiago de Compostela.

PEÑA SANTOS, A. DE LA, 2001, Santa Trega. Un poblado castrexo-romano. Ourense.

PEREIRA GARCÍA, E. e HIDALGO CUÑARRO, J. M., 1999, Dos modelos de hábitat castreño en el Val do Fragoso: Castro de Vigo e Isla de Toralla. Revista de Guimarães, volume especial 1: 431-450.

PÉREZ SUÑÉ, J. M. y REVILLA CALVO, V., 2000, Las producciones béticas y el consumo urbano: Iluro y su territorio. En Congreso Internacional ex Baetica Amphorae (Sevilla - Écija, Diciembre 1998). Écija, 593-603.

RAMÓN, J., 1995, Las ánforas fenicio-púnicas del Mediterráneo central y occidental. Col.lecció Instrumenta 3. Barcelona.

REY CASTIÑEIRAS, J. 1990-91, Cerámica indígena de los castros costeros de la Galicia occidental: Rías Bajas. Valoración dentro del contexto general de la Cultura Castreña. Castrelos 3-4: 141-163.

RODRÍGUEZ MARTÍNEZ, R., 2005, Análise dos materiais exhumados. En X. Ayán Vila (coord.): Os Castros do Neixón, Boiro, A Coruña. A recuperación dende a arqueoloxía dun espazo social e patrimonial. Noia.

SAGONA, C., 2002, The Archaeology of Punic Malta. Ancient Near Eastern Studies 9. Herent. 
SERRANO, E., 1995, Producciones de cerámicas comunes locales de la Bética. En Cerámica comun romana d'época Alto-imperial a la Peninsula Ibérica. Estat de la questió. Monografies Emporitanes VIII, Ampurias, 227-249.

SILVA, A. C. F. DA, 1986, A Cultura Castreja do Noroeste de Portugal. Paços de Ferreira.

SUÁREZ OTERO, J., 2004, Cerámicas iberopúnicas do Castro de Alcabre. En F. Singul and J. Suárez Otero (eds.): Até o confín do mundo: Diálogos entre Galicia e o mar. Catalogue of the exhibition, 38. Vigo.

SUÁREZ OTERO, J. y FARIÑA BUSTO, F. (1990): A Lanzada (Sanxenxo, Pontevedra), definición e interpretación de un yacimiento castreño atípico. Madrider Mitteilungen 31: 309-337.

TONIOLO, A. y FAYAS, B., 2002, Comercio di contenitori di transporto a lungo corso tra Meditarraneo Tirrenico e Mallorca nel III-I secolo a.C. En: Kha- noussi, M., Ruggeri, P. y Vismara, C. (eds.): L’Africa Romana. Atti del XIV Convegno di Studio (Sassari, Diciembre 2000). Vol. 1. Roma: 697-710.

TORRES ORTIZ, M., 2005, ¿Una colonización tartésica en el interfluvio Tajo-Sado durante la Primera Edad del Hierro? Revista Portuguesa de Arqueologia 8(2): 193-213.

VÁZQUEZ VARELA, J. M., 1977, Estudio de la fauna marina de los concheros de los castros de A Peneda y Montealegre (Pontevedra). Gallaecia 1: 143-146.

VEGAS, M., 1973, Cerámica común romana del Mediterráneo occidental. Barcelona.

VILA FRANCO, $\mathrm{M}^{\mathrm{a}}$. I. Estudio numismático. En R. Aboal y V. Castro (eds.): O Castro de Montealegre (Moaña, Pontevedra). Noia: 235-244.

Recibido el 30-10-06 Aceptado el 12-03-07 